\title{
The famine of 1921-22 in the Crimea and the Volga basin and the relief from Turkey
}

\section{Hakan Kirimli}

To cite this article: Hakan Kirimli (2003) The famine of 1921-22 in the Crimea and the Volga basin and the relief from Turkey, Middle Eastern Studies, 39:1, 37-88, DOI: $10.1080 / 00263200412331301597 a$

To link to this article: https://doi.org/10.1080/00263200412331301597a

Published online: 15 Dec 2010.

Submit your article to this journal 둔

Џlll Article views: 130

Citing articles: 1 View citing articles 


\title{
The Famine of 1921-22 in the Crimea and the Volga Basin and the Relief from Turkey
}

\author{
HAKAN KIRIMLI
}

In 1921-22, a famine of unprecedented proportions swept through several regions of Soviet Russia. Although crop failures and even large-scale famines had been plentiful if not periodical in Russian history, what occurred then surpassed anything in the past in terms of both its geographical magnitude and the number of people who suffered from it.

The impending disaster had been signalled already in 1920. Then Russia was severely enfeebled by the combined calamities of a long-lasting war, revolution, internal strife, terror, banditry, disease, and disorder. Industry, trade, and transportation were all in a shambles. The new Bolshevik order was actually one of the main causes of the situation rather than a factor alleviating it. The Bolshevik policies of 'Red Terror', the introduction of 'class war' in the countryside, and the 'War Communism', characterized by the forcible requisitions which often meant the confiscation of grain which had been set aside for the very survival of its producers, crushed the peasantry. Moreover, in summer 1920, an awful drought overcame large parts of central Russia and the Volga basin. It was to repeat itself in the following year. ${ }^{1}$

By the spring of 1921, all signs of a devastating famine were clearly in sight. Soon, the catastrophe spread all over the Volga basin, the Urals, and later, the Don basin, Ukraine and the Crimea. The number of people who were struck by the disaster, incoherent though the figures are, far exceeds 30 million throughout the famine period. ${ }^{2}$ The number who died due to the famine was estimated at around ten million. Some one-third of this number died directly from starvation, whilst most of the rest who had been severely weakened by hunger were killed by the diseases that rampaged under the ruinous circumstances of the famine. ${ }^{3}$ The horrors of the famine included the massive death rate, epidemics, desperation, cannibalism, collapse of order, total consumption of anything edible, and more. No less important than the extent of the famine and the huge number of the suffering and dying was the fact that the famine-stricken areas comprised the basic grain producing regions of the Soviet lands in terms both of quantity and quality.

Middle Eastern Studies, Vol.39, No.1, January 2003, pp.37-88 PUBLISHED BY FRANK CASS, LONDON 
Initially, the Soviet government refused even official acknowledgement of the events until July 1921. It was able to provide relief only to a fraction of the starving people who were in desperate need of urgent aid. ${ }^{4}$

As attempts to handle the situation from its own resources and methods soon proved utterly insufficient, Moscow reluctantly sought international relief. On 13 July 1921, Maksim Gorkii, the renowned writer, no doubt upon the initiative of the Soviet leadership, issued an appeal to the world asking for food and medicine for the victims of the famine. The formal communiqué of the Soviet government signed by Georgii Chicherin,the People's Commissar of Foreign Affairs, addressed to the 'Heads of All Governments' came on 2 August 1921. Having described the situation in carefully selected words, Chicherin wrote 'the Soviet government welcomes the help of all providing it does not involve political considerations'. Vladimir Lenin, like many among the Bolshevik leadership, was not hopeful of assistance from the capitalist powers and was deeply suspicious about their motives if such relief were to materialize. Rather, he would expect, and prefer, the help of the 'international proletariat' to be organized by the Communist International. ${ }^{5}$ In July 1921, the 'All-Russian Public Committee to Aid the Starving' (Vserossiiskii Obshchestvennyi Komitet Pomoshchi Golodaiushchim, abbreviated to Pomgol) acted as the chief public organization to organize relief.

The first response to Gorkii's appeal was from Herbert Hoover, the then US Secretary of Commerce and the future President of the USA. Hoover was also head of the largest relief organization in the world, namely the American Relief Administration (ARA). Having signed an agreement with the Soviet authorities, the ARA commenced its operations in September 1921. Another agreement was signed in August 1921 in Moscow between the Soviet government and Dr Fridtjof Nansen, the Norwegian philanthrophist who was designated High Commissioner for Russian Relief on behalf of the Geneva Conference. The British relief organizations, Save the Children Fund and the Society of Friends, and the Swedish Red Cross were to work under this latter agreement. ${ }^{6}$ In autumn 1921, the League of Nations in Geneva discussed the relief work for the famine-stricken people of Russia. A special commission was set up under Joseph Naulens, the former French Ambassador to Russia. As Naulens' anti-Bolshevik leanings were well known, the Soviet government denied the commission entry to Russia. On 6 October 1921, the representatives of Great Britain, France, Belgium, Italy, Germany and a number of other states met in Brussels to discuss the Russian famine relief. They decided to offer Russia credits, provided that the latter recognize the debts of the tsarist era. The Soviet government was forced to submit to this condition. ${ }^{7}$ 
The horrors of the famine were well publicized abroad through shocking accounts in the western press. Throughout the famine period, varying amounts and types of aid poured into Soviet Russia from all over the world, including almost every country in Europe, as well as Argentina, Uruguay, Cuba, Australia, South Africa, Iran, Afghanistan, and many others. ${ }^{8}$ Though millions of victims lost their lives and others suffered enormously, the foreign relief work substantially helped to alleviate and contain unspeakable calamities. Among the foreign relief organizations, the most important was by far the ARA, which channelled some 540,000 tons of food over a twoyear period and sustained over 10 million people at the height of its activities (as also verified by the Soviet authorities). ${ }^{9}$ The ARA centres in Kazan, Saratov, Orenburg, Samara, Simbirsk, Ufa, and the Crimea, which provided crucial food and other relief work to the local population, were to function incessantly until June-July $1923 .{ }^{10}$ Other foreign relief organizations were to feed some three million starving people in Soviet Russia by providing a total of over 2 million tons of foodstuffs during the famine period. ${ }^{11}$

Among the most severely famine-stricken lands in Soviet Russia were the Volga basin and the Crimea, with large Turkic/Muslim populations. Indeed, the provinces of Samara and Chelyabinsk, and the German Autonomous Republic on the Volga and the Bashkir Autonomous Republic (the combined population of which declined by 20.6 per cent) suffered the greatest human losses. ${ }^{12}$ The situation in the Tatar Autonomous Soviet Socialist Republic was hardly better.

During the winter of 1921-22, famine in the Volga basin was at its peak. The situation was worst in the countryside, particularly in those areas far from the railways. ${ }^{13}$ Even in cases when some food aid was available along the railway routes, people such as the Bashkirs who lived in the woods, as well as others who pursued animal husbandry, could not fetch it since their horses were dead and they were too exhausted themselves to do so alone over the snow-covered terrain. ${ }^{14}$

The dearth of any food led the people to consume many otherwise inedible stuffs, such as tree bark, grasses, leaves, and even a kind of clay. Those who were able to bake 'bread' using wild grasses, tree leaves, or tree bark were considered among the luckier ones. In cases when these ingredients did not suffice, animal manure would be added to bring the 'bread' to a consistency. Wild or stray animals like dogs, cats, mice, rats, squirrels, frogs, and various kinds of other rodents and sizeable bugs were hunted and eaten. ${ }^{15}$ There were widespread cases of cannibalism. Reports testified to cases of devouring the bodies of even closest relatives such as 
their own children, brothers and sisters. ${ }^{16}$ Such horrific cases of cannibalism were not confined to already dead bodies. Indeed, some people even killed others, especially children, to eat. ${ }^{17}$ As thousands of starving and almost delirious peasants abandoned their homes in a desperate hunt for food, they often left their children behind, thus sealing their fate. ${ }^{18}$ There were also cases of parents killing their own children to save them from a worse and slower death. ${ }^{19}$

The collapse of the water supply, sewerage, and all sanitation systems signalled further disaster in the Volga basin. The neglected streets of Kazan, for instance, were covered with refuse and excrement; the cisterns, which formed the sewerage system, overflowed.$^{20}$ Not surprisingly, the famine was accompanied by widespread epidemics in the region, a fact which required medicine no less than food aid. Clothing was also urgently needed for thousands of people who were left almost naked.

The ARA aid reached the Volga basin as early as September 1921 and the decision of the US Congress to offer $\$ 20$ million for the victims of famine in Russia especially expanded its work. The ARA provided large amounts of foodstuffs, clothing, and medicine. By the end of January 1922, the ARA opened public kitchens in almost every starving place in the Volga basin. The amount of foodstuffs brought by the ARA to the region amounted to 5,213 loads (more than 80 million kilograms) by May 1922. ${ }^{21}$ Despite its vital role, the ARA work in the Volga basin was, of course, not free of political impediment and suspicion. At one point, three Russian employees of the ARA in Tatarstan were arrested by the local authorities. They were freed only on the ARA's threat to stop food shipments. ${ }^{22}$ The ARA also helped to link the Volga Tatar diaspora by appeals to help their brethren in their homelands. The Volga Tatars in Finland sent individual parcels of food to men of letters and religion in the Volga-Ural region. Apparently, the first consignment of such parcels was delivered to their addresses in early 1922 and the third delivery was received in early August $1922 .^{23}$ This timely help was deeply appreciated by the intellectual, literary, scholarly, and religious elite of the Volga-Ural Turks, most of whom were in a desperate situation. ${ }^{24}$

The relief work of the ARA, Pomgol, Russian Red Cross, German Red Cross, Swedish United Committee, and many other domestic and foreign organizations was a help but could hardly defeat the catastrophe. There were also ominous signs and little hope for the following year. In addition to the fact that the lack of manpower allowed only a small part of the land to be sowed, most of that prospective harvest was burned by the drought during the summer of 1922 or destroyed by worms. ${ }^{25}$

The way the Soviet government assessed and handled the crisis was hardly compatible with these developments. By summer 1922, quite 
sanguine pictures of the end of the famine and overly rosy prospects for the harvest began to appear in the Soviet press. They became more meaningful when accompanied by implicit or explicit comment that, having overcome the famine, Soviet Russia could resume exporting grain. ${ }^{26}$ Although the fallaciously optimistic portrayals of the 'end of the famine' were blurred soon by unconcealable facts, the Soviet government declared its policy change from direct famine relief to individuals to "liquidation of the consequences of the famine'. Thus, on October 1922, Pomgol was replaced by Posledgol, that is, the Central Commission for the Struggle against the Consequences of the Famine, on 15 October 1922. Stripped of the pretentious rhetoric of its official list of tasks, in practical terms, most of the functions of the Posledgol were in the realm of economic supervision and planning. ${ }^{27}$ While these changes were aimed at laying the groundwork for return to general socialist economic objectives, they obviously portended enormous complications and inadequacies in handling the actual situation in the famine areas.

While famine was devastating many other regions of Soviet Russia, the Crimea for some time seemed almost immune to such a catastrophe, in the face of the fertile, exotic image of this 'Green Island'. Even without the famine, however, the Crimea had already experienced its own tribulations and was just emerging from the ruins of a recent cataclysmic period. Having undergone long and extremely destructive years of civil war with alternating rules of so many antagonistic parties and armies since 1917, Soviet power was finally established in the peninsula in November 1920. The aftermath was marked by the severely oppressive period of Red Terror and War Communism. Still, the formation of the Crimean Autonomous Soviet Socialist Republic was to be welcomed as the beginning of a new and promising chapter, particularly for the Crimean Tatars who were considered the 'native' (korennyi) people of this new-born autonomy.

In contrast to many of the famine-stricken regions, the climate seemed to favour the Crimea in the preceding years. The crop failure of 1920 had not hit the Crimea as hard. Actually, in some of its districts the harvest was above average. There was a grain surplus of some 7 million poods in the peninsula during that year. ${ }^{28}$ This initial natural abundance, nevertheless, was nullified by other factors.

During most of 1920, the Crimea exceeded its limits to sustain the armies of generals Anton Denikin and Pyotr Wrangel, as well as hundreds of thousands who had fled before the Bolsheviks and taken refuge in this last 'White' haven. In those days, anarchy, corruption, and epidemics (particularly spotted typhus) ravaged the country. The high-handed rule of 
the 'Whites' was to be replaced by the merciless Red Terror of the Bolsheviks in November 1920. The tax requisitions and punitive measures of the new Bolshevik rule hit the countryside especially hard. Under the conditions of the 'War Communism' which was to be applied until at least the autumn of 1921, freedom of movement, exchange of goods, and the market system were banned. Banditry was widespread. Thus, the 7 million poods of grain surplus of the 1920 harvest was soon wiped out, and the 1921 harvest was to be much below average. The final blow came from nature. A drought caused by the exceptionally hot and dry summer of 1921 , an invasion of locusts, and untimely rain showers led to a miserable harvest. ${ }^{29}$ The harvest yielded some 8.5 million puds less than required. ${ }^{30}$ Few reserves remained and the rest of Soviet Russia was already struggling with famine. Even some Soviet figures were critical that the authorities both at the centre and at local level responded to the problem very poorly. ${ }^{31}$

The seriousness of the situation in the Crimea became obvious as early as August 1921, the same time that a committee (Pomgol) for aid to the victims of famine in the Volga basin was formed in Akmescit (Simferopol) on the instigation of Moscow..$^{32}$ This committee, which undertook the relief campaign for the Volga basin, would later become the nucleus of the Pomgol for the Crimea itself. In the meantime, Moscow was urging the Crimean authorities to receive the victims of famine, especially the starving Tatar children from the Volga basin, in the Crimea. Taxes with high rates were still being collected in the peninsula and even the exportation of local products went on. ${ }^{33}$

The famine in the Crimea emerged first among the Gypsies who had irregular sources of income. Later, the Crimean Tatar peasants in the southern mountainous regions, where almost no crops were cultivated, experienced the famine. The first case of death from hunger was recorded in November 1921. Matters took such a quick turn that the number of deaths reached 1,500 or 2,000 by the end of December $1921 .{ }^{34}$ By then the famine had already spread to the steppe region, bringing the entire peninsula under its sway. The peasants were flocking to the cities in desperation. The Crimean Central Committee for Aid to the Starving (Pomgol) was established on the initiative of the Crimean republican authorities on 1 December 1921. For a long time, appeals of local authorities to Moscow to declare the Crimea a famine area fell on deaf ears. Such official recognition was essential for receiving aid, immunity from taxes, and other special treatment. The delay to a certain extent had something to do with the fact that the Crimean statistical administration had misinformed the central authorities with swollen figures about the harvest in the Crimea. The work of the Crimean Pomgol and other 
government bodies dealing with the famine was also very inefficient until it was too late. ${ }^{35}$

It was on 4 January 1922 that the okrugs of Sevastopol, Yalta, and Canköy were officially declared 'bad harvest' (neurozhainyi) zones. ${ }^{36}$ Moscow was to declare the entire territory of the Crimean ASSR a 'famine zone' only on 16 February $1922 .{ }^{37}$ It was too little, too late: already thousands were dying in the streets. Until then, the Crimeans themselves were expected to face the situation without any help from either the central government or foreign relief organizations. The meagre resources of the peninsula had long been exhausted.

During the first months of 1922, famine in the Crimea reached horrible proportions. The death toll rose to 10,000 in January 1922, 21,000 in February, and 28,000 in March (the worst month of the Crimean famine). Between February and April 1922, practically two-thirds of the peninsula's population were starving. ${ }^{38}$ In April, official reports gave the daily death toll in the Crimea as 1,500 to $1,600 .{ }^{39}$ The hardest hit regions were the entire okrug of Yalta and the raions of Sudak, Karasubazar, Kezlev (Yevpatoriya), Bahçesaray, Kökköz, and Balaklava where virtually everybody was starving. ${ }^{40}$ The situation was most critical for the Crimean Tatars, because these districts held the highest concentration of the population. Reports pertaining to April 1922 attested that some villages in the Karasubazar raion had already lost half their population. Approximately 250 to 300 people were dying in Bahçesaray and 20 surrounding villages, all of which were inhabited overwhelmingly by Crimean Tatars. Thus, it was estimated that - had these figures remained constant during the forthcoming months - one third of the entire inhabitants of the Crimea, or 50-70 per cent of the Crimean Tatar population, would have perished. ${ }^{41}$ As almost all Crimean Tatars were starving, Yurii Gaven, the Chairman of the Central Executive Committee of the Crimean Autonomous Soviet Socialist Republic, aptly portrayed the situation as 'the dying of an entire nation'. ${ }^{42}$

The horrors of the Crimea were not unlike those in the Volga basin and Ukraine. Almost everything edible including all the domestic animals was consumed. Cats, dogs, and other non-domestic animals were also eaten as well. ${ }^{43}$ One eyewitness relates the open sale of slaughtered and butchered dogs. ${ }^{44}$ Cases of cannibalism were also frequently recorded. ${ }^{45}$ Starving peasants flocked to the cities, only to die there. Streets, roadsides, and the railway stations were full of dead bodies and abandoned children. ${ }^{46}$ An Englishwoman who left Sevastopol in March 1922, reported that one of her friends whose duty was to collect corpses for burial found 'on the main streets alone about 60 cases of death from starvation every night'. ${ }^{47}$ Just like the Volga basin, the lack of sanitation 
caused widespread epidemics. Typhoid, fever, typhus, and cholera were rampant. The latter proved to be a great threat, especially in Kefe (Feodosiya) and Kerç. ${ }^{48}$

The famine inevitably led to moral collapse. Prostitution increased significantly: there were many women on the streets who were offering themselves for a piece of bread. ${ }^{49}$ Banditry connected to the famine was also commonplace. Actually, brigandage of both a political and a nonpolitical nature was widespread in the Crimea during and immediately after the Russian Civil War. All the drastic measures of the Bolshevik regime had failed to obliterate this phenomenon. In early February 1922, an 'Extraordinary Troika for the Struggle Against Banditry' and special armed squads were organized. ${ }^{50}$ These politically motivated bands in mountains could be dissolved only by virtue of the general amnesty in May 1922. Nevertheless, the famine fostered every kind of purely criminal banditry. ${ }^{51}$ Robberies of starving people, often accompanied by murder, along with countless cases of theft, were everyday affairs during the famine. When such criminals were caught by the people themselves, rough justice was applied by killing or beating them severely on the spot. ${ }^{52}$

In early summer 1922, a new catastrophe hit Crimean agriculture in the form of a locust invasion from the Kuban region. At a time when manpower was desperately needed in order to till the fields, some 300,000 people were suffering from famine in the Crimea. Thus, the harvest of 1922 proved sufficient only for the few months following its gathering. ${ }^{53}$ The famine which seemed to subside in summer returned, beginning in the autumn of 1922. In November 1922, the death rate started to rise again. By December, the number of starving people reached $150,000 .^{54}$ The famine in the Crimea, which lasted much longer than other parts of Soviet Russia, could be stopped only in 1923.

The overall destruction caused by the famine in the Crimea was enormous. Whereas 719,531 people lived in the peninsula in 1921, this figure fell to 569,500 in 1923 as recorded by the Crimean Statistical Department. ${ }^{55}$ The death toll was no less than $100,000 .{ }^{56}$ More than half the deaths had taken place in the countryside and some 60 per cent of the victims were Crimean Tatars. Many people had also left, or were evacuated from the Crimea. A total of 19,132 people were recorded as such. ${ }^{57}$ As a result of the famine, the population in Karasubazar fell by 48 per cent, in Eskikırım by 40.9 per cent, in Kefe by 35,7 per cent, and in Sudak by 36 per cent. The inhabitants of some of the villages in the mountainous region in the south died out almost completely. ${ }^{58}$ Crimean agriculture experienced a disaster in $1922 .{ }^{59}$ Due to the lack of people and animals to work, the area of the unsown and untilled fields increased enormously, hitting the harvest hard. In line with agriculture as a whole, 
labour-intensive cultures such as vineyards and tobacco - very important sources of income for the Crimea - collapsed. ${ }^{60}$

During the famine in the Crimea, especially in the earlier and worst months of the catastrophe, relief work lagged far behind what was needed to assuage the sufferings of the victims. In fact, at the beginning of the famine, starving peasants were for the most part left to their own means. Until the organization of central relief work, mutual relief committees were spontaneously formed in the relatively less stricken villages and were the only bodies to offer modest help to their neighbours. ${ }^{61}$ When the basic relief body, the Crimean Pomgol was organized, it admitted that not much help could be expected from the centre..$^{62}$ It could only rely on local resources and any possible aid from abroad. Obtaining grain from abroad with cash (gold) or by barter was necessary, although funds were at the moment lacking. Attempts to bring in grain from other parts of Russia by bartering Crimean tobacco and wine also proved unpromising. In order to raise a fund for buying cereals from abroad, the Pomgol began to sell grain to starving people in return for gold and valuable goods. ${ }^{63}$ To this end, special centres were opened in the towns and villages. ${ }^{64}$ At these, grain was exchanged for a variety of articles. When the people ran out of their remaining gold, they began to offer copper goods. Finally, when the copper was also depleted, even the camel wool (ulpaq) used to stuff the mattresses was collected. Certainly, the suffering people who were literally stripped of their last belongings deeply resented these methods ${ }^{65}$ Grain was bought from abroad in return for the collected valuables through the central Soviet foreign trade organs. Such purchases were also made from overseas countries. ${ }^{66}$

One of the initial methods of finding resources was the imposition of a special tax on all citizens. ${ }^{67}$ The Pomgol proposed to utilize the wealth of the local people to the utmost, especially that of the 'passive segments of society' such as the tradesmen, landlords and so on. The Pomgol's proposals also included the imposition of taxes on all movable goods and the confiscation of valuable artefacts from cathedrals. ${ }^{68}$ In fact, the famine gave the Bolsheviks an opportunity to further squeeze the usual scapegoats: the few remaining bourgeois, petty tradesmen, and clerics. To strip the temples of their remaining valuables, a special order was issued. Harsh measures were taken to crush the clerics who tried to resist. ${ }^{69}$ Nevertheless, not much could be confiscated from the churches. In many cases no valuable artefacts could be found, in all likelihood due to the earlier seizures. A tax for children's food rations was imposed on the tradesmen and petty bourgeoisie. ${ }^{70}$ The district (okrug) administrations also imposed taxes on the trade activities and incoming goods to local markets. ${ }^{71}$ Searches were conducted in the houses of relatively better-off peasants (the so-called $k u l a k \mathrm{~s}){ }^{72}$ Whenever hidden food was found, it was confiscated and its 
owner was severely punished. Priceless works of art and other antiquities in historical palaces and mansions in the Crimea were also subject to confiscation..$^{73}$ Alarmed, state officials in charge of historical monuments and scholars appealed to Gaven to stop this practice. ${ }^{74}$

The Crimean Pomgol was in charge of opening free feeding points in the towns and villages. The children who were obviously hardest hit by the catastrophe, had priority access to the limited resources of the Pomgol and the other local relief bodies. As of February 1922, the Crimean Pomgol was feeding some 10,000 to 12,000 children (who constituted only five per cent of all starving children in the peninsula) and 30,000 adults. ${ }^{75}$ Although 'higher calorie' rations were assigned and special shelters opened for children, these were anything but sufficient. Not only was the overwhelming majority of starving children deprived of such 'facilities', these shelters were operating under the most unhealthy conditions and were literally crammed full. The shelters were filthy and airless, and provided little care. Epidemics were rampant in shelters where 'everyday dead bodies were put in a row like logs and taken out of the town' ${ }^{76}$ In one such children's hospital which was normally for 45 patients, 560 children had taken refuge. Moreover, the 'special higher calorie' food rations for children were only one-third of a pound daily. ${ }^{77}$

As almost no outside aid could be provided at the peak of the Crimean famine (March 1922), most of the starving were virtually left to their own fates. ${ }^{78}$ The Pomgol was able to feed 25 per cent of the starving Crimeans in April 1922, and 35 per cent in May. ${ }^{79}$ The Crimean Pomgol was distributing approximately 200,000 rations in June $1922,{ }^{80}$ but even this figure was still much below the required amount which was then estimated at no less than 370,000 rations ${ }^{81}$ Parallel to the change all over the Soviet realm, the Crimean Pomgol changed its name to Posledgol in 19 October 1922 and continued to exist as such until 16 August $1923 .{ }^{82}$ In June 1923, there were still more than 150,000 children and about 12,000 adults who were being fed by the state. The number of the orphans and uncared-for children reached 25,000, while there were 17,000 further disabled and indigent people, as well as 15,000 jobless persons. ${ }^{83}$

In order to receive aid from the other parts of Soviet Russia, the Crimean ASSR was connected to certain regions which were in a relatively better situation, like the Soviet republics of Ukraine, Georgia, Azerbaijan, and the province of Moscow. Apart from the central organs of the Soviet government, the organs and people of these regions were expected to provide relief for the Crimea. ${ }^{84}$ As a part of this connection, the Ukrainian Red Cross sent to the Crimea around 20,000 poods of various foodstuffs between 15 February and May 1922. The Ukrainian province of Kremenchug also shipped three trainloads of food aid in spring $1922 .{ }^{85}$ 
During January-September 1922, a total of 318,091 poods of grain arrived from the other regions of Soviet Russia. ${ }^{86}$

The Crimean government actually dispatched a delegation headed by Ümer İbraimov, the People's Commissar for Agriculture, to Georgia and Azerbaijan to ask for aid. The Crimean delegation requested the host governments to increase the amount of donations and deductions from salaries and wages of working people for the benefit of the starving Crimeans. ${ }^{87}$ While Ümer İbraimov was in Baku, the Second All-Crimean Tatar Non-Party Conference, which convened in Akmescit in early May 1922, adopted an address to the Council of People's Commissars of the Azerbaijani republic and cabled it to İbraimov. The text which bore the signatures of Yurii Gaven and Osman Derenayırlı, the Chairman of the Conference, was characteristic:

In the name of the starving peasants of the Crimea, the All-Crimean Tatar Non-Party Conference appeals to the toiling people of the fraternal republic of Azerbaijan with the urgent call for help in the struggle against the terrible catastrophe of famine. In the Crimea more than 400,000 people, i.e. more than 60 per cent of the whole population, is starving. So far around 75,000 people have died because of the famine and more than 50,000 of them are Tatars. More than one-fifth of the Crimean Tatar population died because of the famine. Taking into account that Azerbaijan itself is experiencing difficulties in food provisioning, the Conference requests help for the starving Crimea with those non-food products which are present in Azerbaijan in abundance: oil, gas, kerosene, etc. ${ }^{88}$

An interesting resolution of the Conference was its demand to send a three-man Crimean Tatar delegation for the collection of donations among the Crimean Tatar diaspora in the Balkans. The Conference also adopted an address to the Council of People's Commissars of Georgia, expressing the gratitude of the Crimeans for the help that the Georgian people extended to the Crimea. This was also extended to the Cominternbacked 'International Workers' Relief Committee' (Mezhrabpom). ${ }^{89}$ A disheartening reply was received from Azerbaijan, which stated that Azerbaijan itself was starving and it would be impossible to expect any significant help from there..$^{00}$

The symbolic political significance for the Soviet regime notwithstanding, the foreign aid the Mezhrabpom could provide was too little, considering the urgent needs. Such foreign relief work was to be crucial in dealing with the famine in the Crimea. Certainly, the single most important source of foreign aid would be the ARA. The ARA, however, came to the assistance of the Crimea rather late. 
When the Crimea was most desperately in need of food aid, ARA was using the port of Kefe (Feodosiya) on the southern littoral of the Crimean peninsula for food shipments to the Volga basin. For example, on 28 February 1922, a large American ship loaded with corn discharged its load on the Kefe port for the people of the Volga basin. Neither the ARA port officials in Kefe, nor its headquarters in Moscow, had been approached by the Crimean or the Moscow authorities to divert some of the relief to the starving people of the Crimea. ${ }^{91}$ The extension of the ARA activities to the Crimea would be realized much later, commencing its work in the Crimea only on 13 May 1922. The ARA activities included feeding, food distribution, and medical care.

Although the local authorities welcomed the ARA, there were problems with the liaison officials sent from Moscow who kept a suspicious eye on the American organization's work. One of these officials who was much more concerned with Bolshevik vigilance than helping the starving people, would describe himself as 'first, a general of the Red Army; second, a member of the Communist Party; and third a relief official'. The feeding services of the ARA began in June 1922. By the next month, it was offering meals for 95,300 Crimean people. ${ }^{92}$ As stated by its Director in the Crimea, Edward Fox, during the peak of its work there the ARA was feeding some 146,000 children, operating 700 feeding stations, and had 150 administrative staff and 3,000 people working in the local feeding stations. The ARA fed Crimean children for 14 months and the adults for 4 months. ${ }^{93}$ In its second year of presence there, the ARA concentrated its activities in the south, while its affiliate the Catholic Mission was to carry out relief work in the Kezlev (Yevpatoriya) region. ${ }^{94}$

Along with the ARA, there were eleven other foreign relief organizations that operated in the Crimea, though none of them were comparable to the ARA in terms of the scale of their work. ${ }^{95}$ Under the Nansen Agreement, the Dr Nansen Mission and the Mennonites were also at work in the Crimea. As of 1 August 1922, the Nansen Mission was feeding 20,000 children and 12,000 adults daily, while the Mennonites were providing food for 20,000 children and 10,000 adults. ${ }^{96}$ The ethnic German inhabitants of the Crimea attracted aid from their kinsmen in Germany. The German mission Feit, which provided food for the starving Germans in Soviet Russia, forwarded 170,000 poods of grain, 100 car loads of corn, and 50 car loads of millet to the Crimea.$^{97}$ In addition, the American Jewish Joint Distribution Committee (JDC or the 'Joint'), the American Quakers, the mission of the Pope, the Dutch and the Italian Red Crosses also provided various relief during the later stages of the Crimean famine. ${ }^{98}$

Further relief was extended to the starving Crimeans from Anatolia through the Turkish Red Crescent. This aid, though quite modest, in view of 
the magnitude of the famine as well as in comparison to other foreign relief efforts, was nonetheless a unique and meaningful page in the history of the 'New Turkey'.

Turkey always had a very special significance for the Crimea and the Crimean Tatars. Not only had Ottoman Turkey played an enormous role in the history of the Crimea, but also the Crimean Tatars were surely one of the closest Turkish peoples to the Turks of Anatolia and the Balkans, in terms of their ethnic, linguistic, cultural, and religious ties. Moreover, since the Russian invasion of the Crimea in 1783, hundreds of thousands of Crimean Tatars had almost continuously emigrated to the Ottoman Empire. As a result of these huge waves of emigrations, the number of the Crimean Tatars who had remained in their homeland became much less than the number of those who had emigrated to Turkey. Political barriers between the Ottoman and Russian Empires notwithstanding, the Crimean Tatars always had a lively interest in Turkey and tried to follow developments there. The ties between Turkey and the Crimean Tatars had taken a novel turn with the national awakening movements of the latter during the decades preceding the Russian Revolution and their attempts to establish an independent Crimean Tatar state in the Crimea which was almost realized in the years 1917-18. It should be noted that the interest, if not the sympathy, of the Crimean Tatars towards Turkey would not be curtailed even after the establishment of Bolshevik rule, if for no other reason than the co-option into the Soviet rule of many members of the former nationalist intelligentsia (the ones who managed to survive the worst times of the Civil War) during the early years of the Crimean ASSR.

It was therefore not surprising that the Crimea sought help from Turkey during the terrible days of the famine. On 2 February 1922, the Presidium of the Central Executive Committee of the Crimean ASSR adopted a resolution to send a delegation to the Grand National Assembly of Turkey in Ankara for providing aid to the starving Crimeans. ${ }^{99}$ This decision was confirmed by the Central Executive Committee of the Crimean ASSR, in its second session on 2-4 March 1922. ${ }^{100}$ It was also decided that the delegation to Ankara would be composed of Hasan Sabri Ayvazov and Mamut Nedim. ${ }^{101}$ Hasan Sabri Ayvazov had been one of the most prominent figures of the earlier nationalist movement and had been elected co-chairman of the Crimean Tatar National Assembly (Kurultay) in 1917. Having managed to survive the initial wave of the Red Terror, he was coopted by the Soviet regime which then sought to enlist the support of what was the Crimean Tatar intelligentsia, temporarily disregarding its nonBolshevik character. This was the case of the young nationalist intellectual Mamut Nedim, a former disciple of the Cedid tradition in the Crimea. ${ }^{102}$ It was quite an apt decision to name Ayvazov head of the delegation to 
Ankara as he was well-known to be fond of and have influential connections in Turkey. Ironically, he used to be the envoy of the antiBolshevik Crimean Regional Government in Istanbul during the last months of the First World War. ${ }^{103}$

The Second Session of the Central Executive Committee of the Crimean ASSR also adopted an 'Appeal to the Grand National Assembly of Turkey'. The Appeal, in characteristic early Soviet jargon, referred to the common struggle of all Oriental peoples against imperialism and hinted at the special bonds between Turks of Turkey and the Crimean Tatars. It also portrayed the Crimean ASSR as the embodiment of the liberation of the Crimean Tatars from the tsarist yoke. 'Revolutionary Turkey' and Soviet Russia were described as barricades against the rapacious rule of world imperialism. The latter was the enemy of all Oriental peoples, including those who joined the composition of the Russian Federation as free national republics. The revolutionary Turkish people were asked to extend relief to their brothers who had gained their freedom in their struggle against tsarism and who were now being destroyed by the famine. It was hoped that this would serve as a further rallying point for the Oriental peoples in the struggle for liberation from imperialism. Groaning under the torment of famine, the Tatar people was requesting the urgent help of the toiling masses of Ankara. ${ }^{104}$

While the Crimea was suffering the horrors of famine, Turkey was undergoing perhaps the most troublesome period of its modern history. Having capitulated after the terribly devastating 'Great War', what was left of the Ottoman Empire was clearly standing on its last legs. The very capital, Istanbul, was under the Entente occupation, large parts of the remaining Ottoman lands in Anatolia were either already occupied by foreign powers or intended to be partitioned in accordance with the provisions of the Treaty of Sèvres which was signed by the Ottoman delegation but was to remain unratified. To supersede the now almost totally nominal rule of the Sultan's government, which retained an impotent existence in Istanbul, a new nationalist government had been formed in Ankara at the heart of the central Anatolian plateau on 23 April 1920. The Ankara government was to conduct a war of independence on three fronts between the years 1920-22. At times, as in the summer of 1921, the advance of the Greek army, which had already invaded most of western Anatolia, threatened even the seemingly secure base of the nationalists in Ankara. Surely, the Ankara government must hold on to the meagre resources which it inherited from the war-torn and bankrupt Ottoman Empire. 
Broken away from the old imperial centre, anathematized by the Entente powers, practically fighting against Entente-supported Greece, and seriously troubled by the new Transcaucasian states, the Ankara government seemed for the moment to be alone on the diplomatic scene. This international juncture, however, was to turn the new Soviet state, the successor to the tsarist Russian Empire which had been considered the principal foe of Turkey during the last two centuries, into something of a strategic ally. Since both regimes were deemed to be political outcasts and diplomatic loners in the Entente-dominated immediate post-war years, a natural rapprochement developed between Ankara and Moscow. Not surprisingly, Soviet Russia was one of the first states to recognize the Ankara government and to establish diplomatic relations with it.

The most critical issue in the relations between the two governments was the financial and military aid of Soviet Russia to the nationalist government in Ankara, which was in immediate and dire need of it. As Entente control over Turkey was exceedingly unacceptable to the Bolsheviks, sustaining an 'anti-imperialist' and friendly Turkey at the southern flank of the young and not-so-stable Soviet regime was of momentous concern. Moreover, Soviet Russia's support of a country fighting against the imperialists would contribute properly to the image for which Soviet Russia strove: the defender of oppressed peoples. This was especially true in order to impress the Oriental peoples. As it had been deemed vital to 'awaken' the East against the imperialist West, young Turkey might have constituted a pilot ally in the region. This would be the case, even if the immediate bolshevization of Turkey would prove to be an impossibility. For the time being, a benevolent and anti-Western regime in Turkey would be sufficient.

In this propitious atmosphere of relations between the two governments, a remarkable episode was the modest famine relief provided by the Grand National Assembly of Turkey. The Ankara government was notified about the famine in Russia quite early through its mission in Moscow and acted accordingly. On 3 September 1921, Mustafa Kemal Pasha [Atatürk], the Chairman of the Grand National Assembly, informed Ali Fuat Pasha [Cebesoy], the Turkish ambassador in Moscow, about the Ankara government decision to appropriate 40 per cent of the grain stored in the depots in certain regions of the Anatolian Black Sea littoral as aid to Soviet Russia. ${ }^{105}$ Apparently the grain at issue was the entire harvest of the sancak of Samsun, as was indicated in a letter by Georgii Chicherin, the People's Commissar of Foreign Affairs, to Ali Fuat Pasha a few days later, expressing the gratitude of the Soviet government to Ankara. ${ }^{106}$ On 18 September 1921, 
Yusuf Kemal Bey, the Foreign Minister of the Ankara government, notified Natsarenus, the Soviet minister plenipotentiary in Ankara, that apart from the previously mentioned 30 tons of maize stored in Ereğli on the Black Sea coast, his government had decided to send 800 tons of cereals and pulses to Russia. ${ }^{107}$ On 27 September 1922, the Soviet People's Commissariat for Foreign Affairs, having thanked Turkey for the Ankara government's help, asked Ali Fuat Pasha about the ports where the shipments would take place. $^{108}$

It should be noted that the Ankara government's sending of famine relief to Russia took place in an extremely critical and eventful period. First of all, the great Greek offensive into the heart of Anatolia striving to smash the backbone of the Turkish resistance once and for all had proceeded successfully with the occupation of huge areas of central Anatolia. Indeed, the Greeks could only be stopped on the banks of the Sakarya River in Central Anatolia, at certain points less than 100 kilometers away from Ankara. The battle of the Sakarya lasted from 13 August to 13 September 1921 with the exertion of enormous force, and losses on both sides. In the end, the Turks succeeded in holding this last line of defence firmly and the Greek army was routed completely. The battle of the Sakarya was certainly the turn of the tide in the war. During this battle, arms and supplies which were received as a part of the Soviet military aid were effectively used and played a role in the Turkish victory.

Apart from these critical events on the western front, highly significant developments were taking place in the east of Turkey too. On 22 September 1921, the ratified versions of the Treaty of Moscow which established and shaped diplomatic relations between Ankara and Moscow were exchanged by signatory parties in Kars. Four days later, the Kars Conference, which was to determine the ultimate map and political structure of the Transcaucasus, was opened with the participation of the Turkish, Russian, Armenian, Azerbaijani, and Georgian delegations. As the last three delegations represented the recently Sovietized states, the actual issue was between Turkey and Soviet Russia. The Treaty of Kars, signed on 13 October 1921, actually confirmed and reiterated the Treaty of Moscow, by shaping the final borders in the Transcaucasus between Turkey and Soviet Russia. It was in the midst of these heated events in September 1921 that the Ankara government sent famine aid to Soviet Russia. There is little doubt that considerations of making a diplomatic and emotional gesture at this very critical juncture of events must have played a role beside purely humanitarian concerns. Still, this could hardly degrade the significance of the aid of the Turkish government which was at that very moment in dire need of every kind of supplies itself (in fact, the grain earmarked for Russia was part of the requisitioned harvest). In any case, this first delivery of 
Turkish famine relief to Soviet Russia was a product of diplomatic process rather than a consequence of public stimulation. The later relief efforts of Anatolia would take place with the direct involvement of the Turkish people, when the latter would be informed much more about the situation in the Volga-Ural region and the Crimea, especially about the plight of their kinsmen in these lands.

Within the context of relations between Moscow and Ankara, the Crimea was expected by the Soviet side to play an exemplary role in its treatment of Turkic/Muslim subjects. In the very formation of the Crimean ASSR, its prospective impression of Turkey was taken into primary consideration. One of the articles published in Zhizn' Natsional'nostei, which was known to reflect the contemporary nationalities policy of Soviet Russia, read:

... the Crimea is the bridge to the Near East, and one way or another the destiny of the revolution in the Crimea will find its direct echo among the Muslim peoples of the neighbouring countries, especially those of Turkey. The fact of the matter is not only the geographical proximity, but also the cultural interactions, which had come into being thanks to the Tatar emigrations to Turkey throughout the entire course of the Russian rule over the Crimea. ${ }^{109}$

Indeed, Crimean events always found their echo in Turkey. Thus, despite great troubles in the domestic agenda, developments in the Crimea continued to be covered from time to time by the press both in Istanbul and Ankara, though not without misinterpretation due to the lack of direct, reliable, and regular information. By and large, the Turkish press had not forgotten the Bolshevik atrocities in the Crimea in 1917-18, but still there were great hopes of a promising future in the new era for the Crimean Tatars hand in hand with Soviet Russia. The account of an interview with a man who had recently arrived from the Crimea, testified to these hopes by praising the national consciousness and cultural awakening of the Crimean Tatars under the new rule. He explained that the victory of the Turkish army which stopped the advance of the Greeks on the banks of the Sakarya river in August 1921 created an extraordinary joy among the Crimean Tatars who performed special mass prayers in the mosques to express their thanks to God on the occasion. He also stated that the Crimean peninsula was hitherto unaffected by the famine with the exception of Yalta and its surroundings. This piece, which appeared on 16 November 1921, was possibly the first mention of the Crimean famine in the Turkish press. ${ }^{110}$ In early January 1922, news items appeared both in the Istanbul and Ankara press that the Crimea had declared independence or considerable autonomy to the extent 
of full self-rule in internal matters with the right to establish direct diplomatic relations with foreign countries. The two papers in Ankara, which always reflected the line of the nationalist government, were jubilantly celebrating this new 'independent fraternal Turkic country'. ${ }^{111}$ As overly optimistic as these interpretations of the events in the Crimea might be, such conceptions (or misconceptions) would still be important in determining the perception of the Turkish public towards the Crimea in the forthcoming months.

On 12 February 1922, a brief news item in the Istanbul daily Vakıt announced that the 'Crimean independent republic' had decided to send a delegation to Ankara in order to establish relations with the government of the Grand National Assembly. According to this information, the Crimean delegation which was expected to arrive in February 1922 was to be headed by Hasan Sabri Ayvazov. This visit was hailed by Vaktt, as the recognition of the Ankara government by 'another independent government in the East'. ${ }^{112}$ This news item did not mention anything about the famine and considered the prospective visit of Ayvazov's Crimean delegation in the context of the liberation of the Crimean brethren. Another news item in the Istanbul press a month later informed the Turkish public about the expected arrival of 'a special delegation in the name of the Crimean, Bashkir, Kirghiz, and Tatar Muslims' to Ankara. This united delegation was to include Hasan Sabri Ayvazov (in the name of the Crimean Tatars) and Abdullah İsmet, the director of the School of Oriental Studies in Moscow (in the name of the Bashkirs). Whether such a visit (which did not take place in the form mentioned) had to do with the famine (as seemed quite logical) or not, is unclear from the information that originated from a source in Ankara. ${ }^{113}$

At this time, the Turkish public, in general, was not yet informed and activated about the famine in the Crimea or about Turkic/Muslim victims of the Russian famine elsewhere. This is not to say that no information was given in the Istanbul papers about the Russian famine in general. However, the fact that millions of Turks and/or Muslims were also starving to death did not initially become clear to the Istanbul press which lacked direct channels of information from Russia. Apparently, the first pieces of information about the famine in the Crimea began to be publicized in late March. It seems that the 'Tatar Charitable Society' (Tatar Cemiyet-i Hayriyyesi) was the first organization in Turkey to learn about the disaster in the Crimea and to take action. The Tatar Charitable Society, which was the main association of the Crimean Tatar immigrants in Turkey, was based in Istanbul and had a number of branches in those localities with several Crimean Tatar settlers. Founded soon after the Ottoman Revolution in 1908, the society was the oldest Crimean Tatar association in Turkey. ${ }^{114}$ Upon 
receiving the news from the Crimea, the Tatar Charitable Society quickly organized a campaign to collect donations for the benefit of the victims of the famine in the Crimea. ${ }^{115}$ The Society also applied to the Ottoman Red Crescent Society which contributed 2,000 Ottoman liras. ${ }^{116}$ Being able to contribute in cash, in fact, the General Centre of Red Crescent Society in Istanbul considered that not much aid could be obtained through the limited means of the Ottoman capital. Therefore, the General Centre applied to its delegation in Ankara which was functioning practically as a parallel Red Crescent centre next to the Grand National Assembly, to undertake the relief work, possibly intending to extend its influence into the Anatolian hinterland. Another reason for the General Centre's relegation of relief work to Ankara was the latter's relations with the Soviet Red Cross. ${ }^{117}$

The Tatar Charitable Society announced its campaign to the public with a declaration depicting the horrors of the famine. Thereby, it was announced that the Society's campaign was being conducted in co-operation with the Red Crescent who would oversee the whole process and whose receipts would be offered to the donors. The collected donations were to be 'sent primarily to the Crimea in view of both its proximity for transportation and its population being as small as about one and a half million [sic!]; if the donations would reach a considerable amount, then they were to be dispatched to the Volga basin as well. ${ }^{118}$ Initially the Tatar Charitable Society also faced the problem of feeding and accommodating individual refugees who fled from the Crimea due to the famine. Having initially assessed the condition of such persons and determined that it surpassed the limited means of the Society, they turned to the Red Crescent for further care. ${ }^{119}$

On 7 April 1922, a distinguished Crimean Tatar politician, Cafer Seydahmet [Kırımer] arrived in Istanbul from Switzerland ${ }^{120} \mathrm{He}$ was one of the architects of the Crimean Tatar National Kurultay and the former Director (Minister) of War and Foreign Affairs in the Crimean government in 1918. He had fought against the Bolsheviks. When it became impossible for him to work in the Crimea, he left for Europe to represent the Crimean Tatar independence cause there. A well-known figure among the political and intellectual circles in Istanbul, he met there Turkish dignitaries and gave interviews to the press. In these interviews, he gave an account of the catastrophic situation in the Crimea and asked the Turkish people to help their Crimean Tatar brethren immediately. ${ }^{121}$ His contacts, however, were not confined to the Ottoman circles in Istanbul. In fact, he was in touch with the representatives of the Ankara government in Europe, and through them even with the Bolsheviks. He explained the purpose of his activities in Europe and in Turkey as twofold: to provide aid for the starving Crimeans and to lobby for the full or at least internal independence of the Crimea. ${ }^{122}$ 
On 19 April 1922, he arrived in Ankara. ${ }^{123}$ Apart from campaigning for famine aid, he hoped to make use of the good relations of Ankara with Soviet Russia in order to obtain political concessions from the latter for the Muslims there, especially for the Crimean Tatars. ${ }^{124}$

Incidentally, just a day before Cafer Seydahmet's arrival, on 18 April 1922, Hasan Sabri Ayvazov and Mamut Nedim as the representatives of the Crimean ASSR also came to Ankara. ${ }^{125}$ It was a strange turn of the wheel of fortune that Cafer Seydahmet and Hasan Sabri Ayvazov, two of the most prominent names of the Crimean Tatar national movement before and during the Russian revolution, being close friends and fellow travellers, found themselves formally representing two strictly opposite camps in Ankara. ${ }^{126}$ As a representative of the Soviet power, Ayvazov had to work mainly through the diplomatic and formal channels of the Soviet mission in Ankara. In fact, during his stay there, he would work in the capacity of counsellor at the Soviet embassy. ${ }^{127}$ Although their open co-operation would be politically inappropriate, it would be unthinkable that these two Crimean Tatar nationalist politicians did not have any contact with each other in one way or another during their stay in Ankara. We do not have much concrete information about the activities of Seydahmet in Ankara, though he certainly worked there for the purposes he had stated before. Apparently he kept or was made to keep a low profile in Ankara, most likely in order not to disturb the Soviet embassy. It is noticeable that he gave no interviews to the press and the latter did not bring up his name when he was there. In any case, although Ayvazov stayed in Ankara for several months, Seydahmet left the nationalist capital much sooner and by mid-May had returned to Geneva. ${ }^{128}$ In Europe, he continued his efforts to seek relief for the starving Crimeans from various states and organizations, such as from the Holy See, Egypt and so on. ${ }^{129}$ Later he would particularly utilize the presence of several foreign delegations at the Peace Conference in Lausanne in late 1922 to lobby for the same purpose. ${ }^{130}$

As for Ayvazov, no sooner had he arrived in Ankara, than he started his campaign to activate the Turkish public and officialdom. On 20 April 1922, he gave an address to the Turkish dignitaries at the Soviet Embassy, ${ }^{131}$ to which he apparently attracted a highly respected audience. He offered quite a detailed narrative of the famine in the Crimea and, explaining the reasons for the famine, blamed the successive powers and groups who dominated the Crimea and led it to ruin during the Civil War. He went on to state the figures and horrible episodes of the famine, such as the crazed mothers devouring their own children, the eating of dogs, the absolute inadequacy of the relief, and utter hopelessness. He concluded his speech with the following words: 
We know which sacrifices Turkey is now experiencing. We came here due to our racial, religious, political affiliations. There is a saying: 'He is a brother who is your comrade in the bloody day.' We expect help from our brethren in blood and religion. We prefer a morsel of Turkey to a sack of flour from the Entente. The flour of the Entente will poison us, while Turkey's smallest relief is our remedy. The policy of the Entente brought us famine. Thus, we decided to go to our brethren in blood and religion. ${ }^{132}$

Concrete results were obtained immediately after Ayvazov's conference and an initiate committee for famine relief was formed on the spot with the inclusion of eight eminent deputies from the Grand National Assembly and the General Director of Press. ${ }^{133}$ On the same day, Ayvazov submitted an Address from the government of the Crimean ASSR to the Grand National Assembly of Turkey where the famine was described and relief was requested. ${ }^{134}$

Ayvazov gave another talk with similar content three days later, on 24 April 1922, this time to a larger audience in a public hall. The assembly was deeply moved by the statements of the Crimean representative and on the suggestion of Tevfik Rüşdü Bey (deputy from Menteşe) two permanent committees, namely a national committee (Kırım Açlarına Yardım Heyeti [Relief Committee for the Starving in the Crimea], hereafter the KAYH) and its local subcommittee in Ankara were formed. The national committee was headed by Refet Pasha [Bele], one of the most prominent generals of the Turkish army, and the local one was headed by Abdülkadir Bey, the governor of Ankara. Containing highly respected figures, these two committees were to be the central organs of Turkish famine relief. ${ }^{135}$

The Anatolian press paid much attention to Ayvazov's conferences. Indeed, very sympathetic comments, strongly urging immediate aid, were expressed. ${ }^{136}$ The semi-official Ankara daily Hakimiyet-i Milliyye, having conceded that the old prosperous days and the previous bounty and liberality were long gone for Turkey, commented that the Anatolians would still consent readily to share their crust of bread with their suffering racial kinsmen in the Crimea who were compelled to eat cats and dogs. It wrote, 'Crimean history is mixed with ours and the Crimeans have been amalgamated with us ... The sorrow of the Crimea always makes us heartbroken. Therefore, we should open our hands as well as our hearts and the Crimea must find the remedy it expected from us. ${ }^{137}$

The KAYH commenced its work immediately after its formation, first of all by resolving to open local branches in every administrative centre, from the provincial centres to townships throughout Turkey. The KAYH branches 
would co-operate with the government offices as well as with local notables. The donations were to be collected through the local branches of the Red Crescent Society, which in turn would channel them to a special account in its central treasury. The KAYH also planned to contact the Turkish missions and representatives abroad in order to extend their scope by collecting donations from the charitable sources there. ${ }^{138}$ Other decisions of the KAYH included the organization of a large performance with the participation of Russian and Azerbaijani artists and appealing to the Press Society in Istanbul through its counterpart in Ankara in order to activate the public for the relief campaign. ${ }^{139}$ The KAYH soon notified Ayvazov and the Crimean government about its activities and asked for information about the latest situation in the Crimea. ${ }^{140}$

The KAYH issued a public declaration to announce its activities and called for donations on 30 April 1922. The declaration explained that despite the current troubles Turkey was experiencing, the Turkish people could not remain as mere spectators to such a catastrophe hitting its Crimean brothers within reach of its help. ${ }^{141}$ The same day the Turkish Press Society in Ankara, called the Istanbul and Anatolian press to action 'for the calamity-stricken people of a country who are our brethren with historical, racial, religious ties on the northern shores of the Black Sea. ${ }^{142}$

The Turkish press responded quickly and effectively to these calls. As a matter of fact, already beginning in April 1922, numerous news items, commentaries, and articles emerged in both Anatolian and Istanbul newspapers about the famine in the Crimea. The relief campaign was strongly and persistently supported by the press. A wide range of newspapers reported, with enthusiastic comments, about the latest local contributions to the current campaign. They tried to monitor the latest developments in the Crimea as best they could through the foreign press and occasional visitors and refugees from Russia. ${ }^{143}$ Leading columnists wrote emotional articles inviting the Turkish people to help their kinsmen. Falih Rifk1 [Atay], the famous Istanbul writer, described the starving Crimeans as 'the sufferers without voice'. ${ }^{144} \mathrm{~A}$ teacher from the Anatolian town of Kastamonu, wrote that in spite of the inconveniences of the ongoing independence war, even the poorest man in Anatolia had at least a piece of bread to eat, which even the wealthiest person in the Crimea lacked. He reminded the faithful devotion of the Crimeans to Turkey throughout history. ${ }^{145}$ Some papers carried regular captions of slogans reminding their readers about the continuing campaign for the starving in the Crimea. ${ }^{146}$

As it was one of the aims of the KAYH to extend the relief campaign abroad, it took a number of steps accordingly. To this end, Refet Pasha cabled Hamid Bey [Hasancan], the Deputy-President of the Red Crescent 
Society in Istanbul on 14 May 1922 to alert the world's public to the plight of the Crimean Tatars through the Agence Havass. ${ }^{147}$ One of the connections of the KAYH abroad was the patriotic Türk Yurdu (Turkic Homeland) societies in a number of cities in Europe, which were mostly attended by the Turkish students there. The Türk Yurdu societies had a markedly patriotic/ nationalistic character and many Turkic individuals from the former Russian Empire also joined their activities. The KAYH asked these societies to spread the word and contribute to the relief campaign for the starving Crimeans, which they fulfilled from their modest means. ${ }^{148}$ The KAYH also appealed to the International Committee of the Red Cross and Muslim organizations abroad. The former replied that it had already offered relief for the Crimea and asked for further updated information. An interesting response came from Marshall Louis Hubert Gonzalve Lyautey, the French Resident-General in Casablanca, on 22 June 1922. The Marshall stated that, upon receiving the telegram of Refet Pasha, he had notified his government about the predicament of the Crimeans and recommended urgent relief for them. ${ }^{149}$ Marshall Lyautey was already known for his initiatives in collecting donations and for his appeal to the French Red Cross to organize a campaign there as early as May $1922 .{ }^{150}$

Initially, the KAYH also envisaged bringing a number of Crimean Tatar children to Anatolia and distributing them among the villages and households there. ${ }^{151}$ In fact, the issue of taking care of the Turkic/Muslim children escaping from the famine in Soviet Russia had been a serious concern for the Turkish authorities during 1922. Apparently no later than March 1922, Kâzım Karabekir Pasha, the Commander of the Eastern Front, warned Ankara about the impending flow of several thousands of Muslim children from Russia. Karabekir Pasha had been informed that hitherto some 10,000 Muslim children had been sent from the starving regions of Russia to Georgia, and the arrival of another 10,000 had been expected in Azerbaijan. According to this information, already some half of these hapless children had perished on the way, and hardly any better fate awaited the survivors as the circumstances in the Transcaucasus were far from hopeful. Thus he found it imperative to settle them in Anatolia in order to save them. He was able to settle and foster some 2,000 of them in the eastern regions of Turkey, but was forced to cable Ankara on 21 March 1922 , because of the lack of adequate resources to take care of the rest. ${ }^{152}$ Thereupon, it was decided that the Ministry of Health and Social Welfare would take care of another 2,000. For other incoming children, the Red Crescent and the Society for Saving the Children were to be called to take in 1,000 children each. ${ }^{153}$ The issue of fostering starving Turkic children 
from Russia was brought to the Grand National Assembly platform by Soysallı İsmail Subhi Bey [Soysallığlu]. He was a deputy who had recently returned from a special mission to Russia. There he had personally witnessed, and had been deeply affected by the famine. Ismail Subhi Bey presented a motion to the Grand National Assembly about the issue, on 3 April 1922. It read:

In Russia, the famine in the Ural and Volga regions is of shuddering dimensions. Those who are most affected by this are the Muslim Bashkirs, Tatars and Kazak-Kirghiz. It is a very important humanitarian and economically urgent matter to bring these starving people, especially the children, to our country and to settle them in the provinces, districts, and villages possibly by official means or by private families. I propose the establishment of a special commission $\ldots$ for the distribution of $20,000-30,000$ children to various parts of our country. ${ }^{154}$

In espousing this motion, Ismail Subhi Bey accepted that there were children who needed care in Turkey too, but none of them were in such a miserable and hopeless situation as the ones in Russia. He proposed that the deputies counsel with their constituencies and arrange private families to accept these children. ${ }^{155}$ During discussion in the Assembly, the deputies almost unanimously agreed that it was primarily a humanitarian duty to help these children despite the presence of so many needy children at home and the lack of means for their care. The deputies were informed of a recent inquiry about the number of orphans in Turkey which found that there was a total of 86,000 orphans in the 33 (out of 59) districts which had replied to the inquiry. Dr Riza Nur, Minister of Health and Social Welfare, confirmed the miserable situation of the orphans in Turkey and considered the distribution of most of the forthcoming children to individual families in the countryside to be the only realistic option. In the end, the Assembly adopted a resolution to form a special commission to deal with the problem. ${ }^{156}$ The commission approached the provinces and received positive responses from a number of them to host and feed children. For the remaining thousands of children, new legislations were deemed necessary. ${ }^{157}$ Later, a member of the commission, Dr Suat Bey [Soyer], presented a bill proposing the deduction of a day's wage from all salaried persons forthis purpose. ${ }^{158}$

Apart from bringing the issue to the parliamentary platform, Ismail Subhi Bey further developed his proposal in a newspaper article, particularly calling for assistance for the Crimea. He did not believe that Turkey, which had been living through the sorrows and destitution of war for the last eight years, could extend any significant relief to the Crimea, let 
alone the distant Volga-Ural. The limited degree of material aid that Turkey could afford would never suffice to remedy the enormous catastrophe there. Therefore, the only way of helping the Crimean Tatars was to 'transport them to our country, if not the adults at least the children!' These people would find bread and accommodation in Anatolia. Even if some of them were to die in the process, most of them surely would be saved. According to Ismail Subhi Bey, this was the only possible and realistic way of relief. ${ }^{159}$

The idea of bringing children from the Crimea to Turkey, however, was not welcomed by the Crimean representatives who had arrived in Ankara. Mahmut Nedim, who replied to Ismail Subhi Bey with an article in the same newspaper two days later, in very complaisant language, plainly refused the idea. He argued that, first and foremost, the health and physique of the children who would be transported were by no means suitable for such a long journey and many of them would surely die on the way. Besides, the travel expenses would be considerable. Moreover, it was not simply a matter of survival for the children. If they were to be distributed to ordinary households, they could hardly receive a proper upbringing. Consequently, concluded Mahmut Nedim, the best solution would be to feed and heal them in their homeland, which would be anyway much cheaper than taking them to Turkey. ${ }^{160}$ Apart from Mahmut Nedim's arguments, there was certainly tacit objection. It had been a cardinal strategy of all Crimean Tatar nationalists for decades to oppose emigrations to Turkey because these had virtually drained the Crimean Tatar population in the peninsula in the course of some 140 years. By contrast, the Crimean Tatar nationalists (such as Ayvazov and Nedim) who had been recruited temporarily by the Soviet regime and obtained government positions, were actually looking for ways to bring back at least some of the Crimean Tatars from the diaspora to the homeland. Therefore, any plan which would involve the emigration of the Crimean Tatars out of the Crimea would be unacceptable to them.

Still, Ayvazov informed the Crimean government about the Grand National Assembly's readiness to accept 10,000 Crimean children over eight years of age. The matter was discussed by the Crimean Central Pomgol which on 9 May 1922 stated that 'in principle the transportation of 5,000 children from the Crimea to Ankara was possible'. ${ }^{161}$ Nevertheless, this project was not realized. Paradoxically, 40 years later, after the mass deportation of Crimean Tatars from the Crimea, the whole matter was presented as a co-ordinated conspiracy of Turkish and Crimean Tatar nationalists. The Stalinist author of a post-deportation Crimean history unjustifiably accused Ayvazov and Nedim of tailoring exportation plans from the Crimea to Turkey. According to him, the plan was rejected by the Soviet government. ${ }^{162}$ 
Although Ismail Subhi Bey's proposal of bringing children from the Crimea to Turkey remained unrealized, the problem of thousands of Crimean Tatar refugees fleeing from famine was a reality. The present figures about the Crimean Tatar refugees to Turkey during the famine are far from being complete and are somewhat confusing. They arrived in Turkey by sea (at Istanbul and Anatolian Black Sea ports) and by land (in the north-eastern provinces). The answers to the questions how, with what status, and where they were registered (or whether registered at all), and which citizenship or passports they carried, will probably remain unclear until the relevant archival sources become accessible, possibly not even then. Yet, these refugees were certainly several thousand in number and there exist at least partial data about the arrivals of individual parties. For example, on 11 April 1922, a group of 500 men, women, and children, transported by the Russian steamer Il'ich, landed at the Black Sea port of Samsun. ${ }^{163}$ By late May, the total number of the Crimean refugees that had descended on Samsun was 2,091. The Turkish authorities then estimated that this figure could well reach 30,000. ${ }^{164}$ During the first half of May 1922, 560 Crimean Tatar refugees arrived in Trabzon via Batumi. ${ }^{165}$ Indeed, Batumi lay on one of the main routes of refugees from Russia to Turkey. Apparently, many such refugees had to stay some time in Batumi. The Turkish General Consulate there, with its limited means, had to care for these people who were in a lamentable condition. ${ }^{166}$ The flow of refugees to the north-eastern provinces of Turkey continued throughout 1922. By February 1923, their number (including those from Iran) reached 14,000. ${ }^{167}$ Although it seems impossible to ascertain the number of famine refugees from the Crimea and other parts of Soviet Russia within this figure, they must have nonetheless constituted a considerable number. In August 1922, at the request of Semyon I. Aralov, the Soviet minister plenipotentiary in Ankara, the Presidium of the All-Russian Central Executive Committee resolved that the 'approximately 1000 Tatars who had fled from the Crimea to Turkey due to the famine' would retain their rights of Russian citizenship. ${ }^{168}$ In comparision with the data of the Turkish sources, the figure mentioned in this Soviet decree was obviously a gross underestimate, if not a deliberate understatement.

In any case, whatever the precise figures might be, the number of the famine refugees to Turkey was certainly a significant one. Yet, they constituted a very small minority of those who wished to do so. ${ }^{169}$ After all, the Soviet regime would allow the departure of those who were not foreign subjects only with great difficulty. Almost insurmountable obstacles impeded the people in getting a passport to leave Soviet Russia. According to one account, such a travel document could not be obtained for less than 3.2 million rubles. ${ }^{170}$ Very few people could afford this. Certainly many 
refugees came to Turkey by illegal means and without passports. Besides, many Crimean Tatars had Ottoman passports which had been acquired a good deal earlier. Therefore, many who were technically considered Ottoman subjects returning to Turkey were actually Crimean Tatars.

The Ministry of Health and Social Welfare, together with the Ministry of Finance, was in charge of the feeding and settlement of the Crimean Tatar refugees. ${ }^{171}$ Most of the Crimean Tatar refugees were settled in the Samsun province. ${ }^{172}$ Those who came via Batumi and Trabzon were to stay temporarily in Trabzon. ${ }^{173}$ The policy of the Ankara government in regard to the settlement of the Crimean Tatar refugees was to have them domiciled exclusively in the Samsun district, possibly in the villages left by the native Pontic Greeks. To this effect, the local circumstances were carefully studied and a certain amount of money was earmarked for the purpose, though it hardly covered the necessary costs. To compel the Crimean Tatar refugees to settle in the Samsun district, it was stipulated that only those who stayed there would be entitled to government help. ${ }^{174}$ It is known that, in accordance with this policy, at least 166 Crimean Tatar refugees (42 households) were settled in the Tepecik village of Samsun. ${ }^{175}$

In face of the grievous situation of the refugees, the Ankara government issued a decree about 'the poor Crimeans who took refuge in our country and who have been utterly exhausted and have lost their body strength due to the long-lasting famine, physiological sufferings and material deprivations'. The decree stipulated that since the food aid offered to the refugees (in accord with the law on the immigrants and refugees) was inadequate to rehabilitate their health in view of their plight, one kilogram of bread per adult (half a kilogram per child) would be assigned for the duration of three months. ${ }^{176}$

As the influx of the Crimean refugees continued in the following months, the Turkish government (Ankara) issued another decree concerning their transportation costs, on 24 August 1922. The decree stipulated that the transportation expenses of the refugees coming from the Crimea to any port within the national boundaries of Turkey would be covered by the Ministry of Health and Social Welfare. The way in which they would be helped was to be determined by the same ministry in accordance with established practice in similar situations. ${ }^{177}$ Later, on 25 October 1922, the capacity of the branches of the Ministry of Health and Social Welfare was enlarged during the budgetary discussions for the next year due to the increasing expenses of feeding and settling the refugees from Russia and the Crimea. ${ }^{178}$

On the other hand, the campaign for donations to the starving Crimeans went on with an extraordinary enthusiasm all over Anatolia. Indeed, the KAYH managed to organize itself very efficiently in a vast area and local 
subcommittees opened even in the remotest towns. This can be explained, apart from the organizational skills of the central KAYH, possibly by the sympathetic stance of the government, the work of the central and local Red Crescent with a wide network of local branches, the effective publicity given to the issue by the press, and last but not least by the genuine feelings and charitable traditions of the Anatolian people who were deeply upset by the news about such a gigantic human catastrophe, involving their religious and ethnic kinsmen. The presence of hundreds of thousands of Crimean Tatar immigrants all over Turkey might be an additional factor in widening the public interest, but this could not explain the magnitude of the concern alone, as so many parts of the country with little or no Crimean Tatar population contributed considerably.

The donation campaign was conducted in a variety of ways in the Anatolian countryside. For the most part, the local (ad hoc) subcommittees of the KAYH or the local branches of the Red Crescent spearheaded campaign. It was not uncommon either to see a local newspaper (for example, Babalık in Konya, Açı Söz in Kastamonu, Yeşil Yuva in Artvin, Ahali in Samsun, Güneş [journal] in Ordu, etc.) actuating or enlivening the campaign by their persistent publications and in fact practically organizing it. ${ }^{179}$ Apart from collecting donations, several fund-raising events were organized: performances, ${ }^{180}$ auctions, ${ }^{181}$ exhibitions, ${ }^{182}$ shares from horse races, ${ }^{183}$ badges, ${ }^{184}$ special tickets, ${ }^{185}$ and so on. The collection of donations was conducted by the personnel of several offices and work places. ${ }^{186}$ The army units were especially active in collecting donations from the officers and soldiers. ${ }^{187}$ Donating one-day's wage by officials, postmen, workers, journalists, and others was witnessed quite often. ${ }^{188}$ The donations for the starving Crimeans were collected in an organized fashion and came from the following cities, towns, and their contiguous townships and villages: Adapazarı, Ertuğrul, Gölpazarı, Mihalgazi, Osmaneli, Bolu, Samsun, Zonguldak, Küre, Ordu, Giresun, Rize, Artvin, Çan, Burdur, Sandıklı, Alâiyye, Mersin, Adana, Seyhan, Kozan, Anamur, Çorum, Sungurlu, Eskişehir, Konya, Beypazarı, Sincan, Polatlı, Kayseri, Sivas, Zârâ, Şarkî Karahisar, Gümüşhane, Maden, Elaziz, Harput, Yümni/Malatya, Siirt, Pervari, Diyarbekir, and Siverek. ${ }^{189}$ Apart from these places (where collections of donations for the victims of the famine in the Crimea could be verified against available documents), there are undoubtly many more places where such activities took place.

At the time when the issue of providing aid for the victims of famine in the Crimea was actively raised among the Turkish public, the Ankara government, which was preparing for the final offensive against the Greeks, was also deeply concerned about receiving further material assistance from Soviet Russia. In April 1922, Mustafa Kemal Pasha asked Aralov, the Soviet 
minister plenipotentiary in Ankara, to remind Moscow about the 10 million roubles package of aid which had been alloted in meetings the previous year. ${ }^{190}$ For the most part, the flow of Soviet armaments and ammunition continued in fairly regular fashion on the eve of the Turkish great offensive in 1922. ${ }^{191}$ Incidentally, the Turkish mission in Moscow experienced a brief crisis in April 1922. Some Turkish diplomats and officers were subjected to search, harsh treatment, and detainment by the Cheka who accused them of engaging in espionage with the Poles in Moscow. Although the crisis culminated with the departure from Moscow of Ali Fuat Pasha [Cebesoy], the Turkish Ambassador, in protest on 10 May 1922, this fortunately did not lead to a rupture in Turko-Soviet relations. ${ }^{192}$ In such a troublesome period, the continuous relief campaign for starving Crimeans, with its great public enthusiasm in Turkey, must have affected these relations favourably. Thus, Aralov cabled Gaven, on 17 May 1922, in elation about the mass campaign in Turkey. ${ }^{193}$

Since the campaigns for donations continued for quite a long time in Turkey, the first shipment of relief materials was ready to be sent to the Crimea by mid-May 1922. By means of the donations, 500 sacks of wheat flour were bought in Ankara. Another 500 sacks of wheat flour was contributed by the General Centre of the Red Crescent bought by money collected through the Tatar Charitable Society in Istanbul. The Soviet mission was also to be informed and asked for exemption from every kind of confiscation and taxes for the relief materials. ${ }^{194}$ Yet the Red Crescent was uneasy about consigning the flour to the Bolshevik authorities in Sevastopol for fear it might not be distributed to the Crimean Tatars. Therefore, the General Centre of the Red Crescent recommended delivery of flour directly to the Muslim co-operative in Akmescit. But the KAYH in Ankara was apprehensive that such behaviour would indicate its distrust of the Russians. Therefore Ankara decided to send the cargo to Sevastopol as previously planned, but accompanied by a delegation which was to oversee the distribution of the flour to the Crimean Tatars. ${ }^{195}$

The delegation to take the relief cargo to the Crimea was composed of two Red Crescent officials, Hasan Bey and İlhami Bey, in the company of Hac1 Mesud Efendi, President of the Tatar Charitable Society. ${ }^{196}$ They left Istanbul on 24 May, and via Novorossiisk arrived in Sevastopol on 31 May 1922. Having stored the flour in a guarded warehouse in Sevastopol in order to contact the Crimean Tatar community, they travelled to Akmescit. There they met a group of Crimean Tatar dignitaries, among them Bekir Sitk1 Çobanzâde (member of the Crimean Central Executive Committee and a famous poet), Selim Memetov (People's Commissar for Foreign Trade), Ümer İbraimov (People's Commissar for Agriculture), Süleyman İdrisov (Counsellor of the People's Commissariat for Agriculture), Seytcelil Hattat 
(President of the Akmescit Tatar Charitable Society), as well as Shvedov (Deputy Chairman of the Crimean Central Executive Committee). The Crimeans expressed their deep gratitude, but politely refused to receive the flour in the name of the Crimean Tatars, stating that feeding the starving was within the authority of the government and wanted to ensure that any discrimination against the non-Tatars was inadmissible. Therefore, in cooperation with Sahibgerey Saidgaliyev, Chairman of the Council of People's Commissars, it was decided to submit and relegate the distribution of the flour to the government and allow local Tatar committees to oversee the distribution. The Turkish delegation was met with tears by the Crimean Tatars. Hasan Bey and İlhami Bey left the Crimea on 10 June 1922. ${ }^{197}$ Hac1 Mesud Efendi stayed in the Crimea for more than two months and visited all Crimean Tatar settlements and institutions on the peninsula. Hacı Mesud Efendi, as well as the two Red Crescent officials, testified that the Crimean Tatars requested not only foodstuffs and clothing, but also insisted on books and newspapers in Turkish for their cultural and educational institutions. ${ }^{198}$ In June 1922, a Turkish diplomat, Veli Necdet Bey (who belonged to the delegation of the Grand National Assembly which went to Kharkov in order to exchange the ratified versions of the Turko-Ukrainian Treaty), visited the Crimea. On his return to Turkey, he depicted the terrible scenes of famine he witnessed in the Crimea in a newspaper interview. ${ }^{199}$ Following the departure of the Turkish officials, the flour was apparently distributed to the starving Crimean Tatars in accordance with their agreement. ${ }^{200}$

Notwithstanding the fact that the famine in the Volga-Ural region preceded the one in the Crimea, as far as the Muslim victims were concerned, the Turkish public heard about the latter before the former and modest relief from Turkey reached the Crimea accordingly. This had certainly to do with the existence of closer contacts between Turkey and the Crimea and the arrival of Crimean Tatar delegations to Turkey asking for relief. However, the Turkic Muslims of the Volga-Ural region had already appealed to their brethren abroad through their main religious organization, namely the Central Spiritual Board of the Muslims of Inner Russia and Siberia. ${ }^{201}$ Dire necessities in the famine had compelled the Soviet regime to use the authorities of the religious institutions, including those of the Muslims. Unlike later decades, during the early years of Soviet rule, most religious organizations were headed and staffed by genuine clerics of the old school, whose religious and scholarly credentials had nothing to do with the Bolsheviks and enjoyed wide respect among believers. So was the case with the Central Spiritual Board of the Muslims of Inner Russia and Siberia which was based in Ufa and headed by the Mufti Rizaeddin Fahreddin, 
whose scholarly standing and fame went much beyond Russia. The Spiritual Board was also filled with several clerics of the cedid tradition. Therefore, the Spiritual Board, or rather its personalities, were highly esteemed abroad and many of them had strong personal connections especially in Turkey.

As with the other religious institutions the way in which the Central Spiritual Board of the Muslims of Inner Russia and Siberia undertook famine relief work and collected donations at home and abroad was strictly regulated. ${ }^{202}$ Apart from collecting donations and feeding people, the Spiritual Board also provided shelter for orphans and homeless children. ${ }^{203}$ The Central Spiritual Board issued an appeal to the 'Muslim Brothers of Muslim Countries' in late winter or early spring 1922. The appeal described the terrible aspects of the famine and emphasized that especially the 'Muslim Turkic peoples (Tatars, Bashkirs, Kirghiz)', who had been economically weakened as a result of the 'colonizing and Russianizing policies of the tsarist regime', were more severely hit by the famine. The appeal called for urgent relief from Muslim peoples and countries; it was particularly stressed that, in accordance with the understanding between the government of the Russian Soviet Federate Socialist Republic and the Central Spiritual Board, the relief from abroad would be distributed exclusively to the starving Muslims supervised by representatives of the Central Spiritual Board. ${ }^{204}$

Apparently, the Appeal of the Central Spiritual Board of the Muslims of Inner Russia and Siberia was penned by Abdürreşid İbrahim, a very prominent political and religious figure among the Turkic/Muslim peoples of the Russian Empire, especially in his role before 1917. When Muslim scholars in the Central Spiritual Board discussed dispatching representatives to Muslim countries including Turkey, Abdürreşid İbrahim vigorously protested. He argued that not only had Muslims been compelled to fight against Turkey as part of the Russian army, but they also remained mere spectators in the current Turkish war of independence in Anatolia. Therefore, in spite of the fact that the Turks of Turkey would give their last morsel at the request of Muslims in Russia, it would be shameful to do so. Yet Abdürreşid İbrahim's objections were overruled and the Central Spiritual Board decided to apply to Turkey for relief and send a deputation to plead their case. ${ }^{205}$ Among the other countries to which the Spiritual Board decided to send delegates were Egypt, Iran, Afghanistan, Lithuania, Estonia, and Eastern Turkestan (Kashgar). ${ }^{206}$ The Central Spiritual Board of the Muslims of Inner Russia and Siberia was not the only Muslim religious organization in the Soviet domain to join in famine relief and call for aid from brethren abroad. The Spiritual Board of the Transcaucasian (Shiite) Muslims, headed by Sheikhulislam Ahund Aga Agaalizâde, was involved in 
collecting donations for the victims of the famine too. It also issued an appeal to the Muslims of the world for help on 23 May 1922. It should be noted that the draft of the Appeal was reviewed and edited by Sergei M. Kirov. ${ }^{207}$

Response to this call came from a number of Muslim peoples such as the Volga-Ural Tatars in Finland, Afghanistan, and Turkey. ${ }^{208}$ It is possible that the success of the campaign for the starving Crimeans in Turkey might have encouraged to the Spiritual Board to appeal to Turkey.

Beside its all-Muslim appeal, the Central Spiritual Board of the Muslims of Inner Russia and Siberia wrote directly to the Ministry of Religious Affairs of the Ankara government. The letter was addressed to Abdullah Azmi Efendi, Minister of Religious Affairs, and signed by Rizaeddin Fahreddin (Mufti) and Keşşafüddin Tercümânî ( $k a d l$ and Chairman of the Central Spiritual Board's Committee of Relief for the Starving). As with other similar appeals, the horrors of the famine were depicted and it was stressed that the Volga-Ural region, inhabited by Muslim Turkic peoples was hardest hit. Warning that at the moment some 12 million Turkic Muslims faced disaster, the letter stated that 'considering that the Ministry of Religious Affairs of the Grand National Assembly of Turkey is the religious core of the Muslim world' the Central Spiritual Board set great on its relief. ${ }^{209}$ The Turkish Ministry of Religious Affairs responded to this letter by issuing a call 'To All Muslims of the World' for urgent help for the Muslims of Russia, thereby declaring that regardless of current fighting against the foreign invasion, Muslims of Turkey having heard the calamity that had befallen fellow Muslims in Russia would forget their own troubles and offer their last morsel to the starving Muslims of Russia. ${ }^{210}$ While the Ministry distributed the original Turkish version of this declaration to the cities and villages in Turkey, Arabic and Persian translations were sent to many parts of the Islamic world. ${ }^{211}$

The Central Spiritual Board sent two esteemed figures, namely Ubeydullah Bûbî, the famous religious scholar and pedagogue, and Tahir Ahmedcanulu İlyâsî, the pedagogue and linguist. It seems that Bûbî and İlyâsî arrived in Istanbul some time in June 1922. They ran into trouble the moment they set foot in Istanbul, as the Entente police who controlled the borders immediately arrested them and seized their passports and other personal documents. They could only be released on the intervention of the Red Crescent authorities in Istanbul, after having spent five days in detention, and even then the Entente police refused to return their documents. Thanks to the documentation provided by the Red Crescent, they were able to travel to Ankara where they could obtain new passports from the Soviet embassy. ${ }^{212}$

During discussions between Bûbî and İlyâsî and the Red Crescent 
authorities, it was decided to extend the current relief campaign for the Crimeans to the 'Muslims of Russia' (read, Turkic Muslims of the Volga-Ural region). In an interview with an Istanbul daily, Bûbî and İlyâsî expressed their intention to issue a declaration about the terrible situation in the Volga-Ural region. They also said that a representative of the Muslims of Russia would travel to Egypt to ask for relief from the Egyptian Red Crescent. ${ }^{213}$ A month later, it was reported in a news item that İlyâsî would visit Egypt. ${ }^{214}$ However, his journey to Egypt was not possible as the British authorities in Istanbul refused him passage. ${ }^{215}$

A long interview with Bûbî in the Istanbul Vakt revealed the latest details of the famine in the Volga-Ural region and the activities of its delegation. In fact, Ubeydullah Bûbî, who was educated together with his brother and sister in Istanbul some 30 years previously, ran one of the most prominent educational institutions among the Volga-Ural Muslims, namely the medrese of (İj Bûbî). Bûbî explained that the roots of the famine went back to tsarist times: not only had the fertile lands been taken from the Muslims, but they were deprived of any agricultural and technical assistance from the tsarist government. Since this left the Turks in the Volga-Ural region economically deprived and confined to primitive and limited forms of cereal agriculture, the drought hit them hardest. He was very cautious not to offend the Soviet regime while explaining the causes of the famine. He described horrible scenes and showed a sample of the 'bread' made of leaves, roots, and seeds of wild plants mixed with clay. The interviewing journalist described the 'bread' as something looking like animal manure. Beside the absence of foodstuffs, Bûbî told of the plea for clothing, as many families had only a single item of clothing which was worn by whoever went out. In places where the temporary bazaars were set up, people would come at night and roll on the floor trying to lick up bits of spilled flour. He invited his co-religionists in Turkey to offer help to the hungry Volga-Ural Turks and stressed that, given special permission by the Soviet government, the Muslim Central Spiritual Board was conducting relief work for the Muslims. ${ }^{216}$

In Istanbul, Bûbî and İlyâsî were joined by Feyzi Bey, a teacher of Tatar origin and an old acquaintance of Bûbî who used to teach at the medrese of Ij Bûbî. ${ }^{217}$ Following the raid on the medrese of İj Bûbî by the tsarist gendarmerie in 1911, Ubeydullah Bûbî and Feyzi Bey had been tried and sentenced to two years in prison. While Ubeydullah Bûbî served his sentence, Feyzi Bey fled to Khiva where he worked as the director of education. ${ }^{218}$ Currently, Feyzi Bey was actively taking part in the famine relief work of the Tatar Charitable Society in Istanbul.

Ubeydullah Bûbî's main destination was Ankara where he intended to meet members of the nationalist government and other dignitaries. 
Accompanied by Feyzi Bey and supported by the Red Crescent, he arrived in Ankara via İnebolu during the second half of July $1922 .{ }^{219}$ It seems that the Volga-Ural deputation found a very receptıve environment for their cause. Owing to constant publicity about the Crimeans, public and press in Ankara were already hat informed and concerned about the famine in Russia in general. Not surprisingly, Bûbî's activities and statements aroused considerable interest in Ankara. In a statement soon after his arrival in Ankara, Bûbî said: '[The Northern Turks] firmly believe that the Anatolian Turks who, despite their preoccupation with a war and jihad against an aggressive enemy, had extended a helping hand to their neighbour, the Crimea, will display the greatest sacrifice of brotherhood by sparing a share from their own morsel for the Northern Turks who constitute a very important component of the great Turkic nation in terms of their number. ${ }^{220}$

During their stay in Ankara, Ubeydullah Bûbî and Feyzi Bey visited Refet Pasha and Ali Fuat [Cebesoy] Pasha, Halide Edip [Adıvar] Hanım, the famous nationalist writer, and Mahmut Esad [Bozkurt] Bey, Minister of Economy. These Turkish dignitaries who gave a warm reception to the Volga-Ural deputation, pledged every kind of help. ${ }^{221} \mathrm{~A}$ concrete result of these meetings was the decision to include the starving Muslims of the Volga-Ural region in the relief campaign for the Crimeansl. Thereby the KAYH changed its name to 'The Relief Committee for the Starving Muslims of Russia' (Umum Rusya Aç Müslümanlarına Muavenet Heyeti URAMMH). Whilst Refet Pasha was elected Chairman of the reorganized committee, Ali Fuat Pasha also joined it; in this way, the total sum of 22,000 Turkish liras which had been hitherto collected by the KAYH was turned over to the new committee.

One of the priorities of the new relief committee was to extend urgent relief to the starving Turkic intellectuals in the Volga-Ural region. It was decided to send individual parcels of aid to such intellectuals through the ARA office at the US Embassy in Istanbul. Ubeydullah Bûbî and Feyzi Bey made a list of the names of several hundred leading scholars, teachers, writers and other intellectuals of the Volga-Ural Turks and submitted it to the Ankara Delegation of the Red Crescent. ${ }^{222}$ The Volga-Ural deputation was received by Mustafa Kemal Pasha, Speaker of the Grand National Assembly of Turkey and Supreme Commander. Mustafa Kemal Pasha briefed the deputation about the current situation in the Crimea and Kazan and of the Muslims there. He said that Anatolia would never hesitate to provide all the help it could to the starving Muslims of the Crimeaand Kazan. ${ }^{223}$

Having fulfilled their mission to Ankara, Ubeydullah Bûbî and Feyzi Bey left for Istanbul via İzmit on 11 August $1922 . .^{224}$ Feyzi Bey, later explained to the İkdam correspondent that Ubeydullah Bûbî and Tahir İlyâsî 
would return to Kazan via Sevastopol on 5 September 1922, while he 'was to stay as the representative of the Northern Turks in Turkey until the famine in the Crimea and Kazan came to an end'. ${ }^{225}$

While the Volga-Ural deputation was touring the authorities in Istanbul and Ankara, the Crimean Tatar representatives, or at least Hasan Sabri Ayvazov, were still in Ankara, continuing to lobby there. Perhaps he was waiting for real fruits of his mission and he might have stayed in Ankara until late 1922. From the beginning of his mission to Ankara, it seems that he knew he had to stay there for a long while. For this reason, he intended to open a Russian language school for Turks in the nationalist capital. ${ }^{226}$ Whether this project was realized is not known but it is certain that he continued his activities to encourage the Turkish public to help his hungry compatriots back home.

One interesting gesture in this respect was the dinner he hosted at his residence in Ankara on 7 July 1922, attended by a distinguished group of guests including the plenipotentiary of Azerbaijan İbrahim Abilov, the deputies Yunus Nadi [Abalığlu], Mahmut Esad [Bozkurt], Tevfik Rüşdü [Aras], prominent journalists and editors from both Ankara and Istanbul such as Aka Gündüz, Lütfi Arif, Ahmed Hidayet, Kemal Salih, Ziya Gevher, İzzet Ulvi and Kâzım, as well as Astakhov, head of the Russian information bureau in Ankara. After the rich meal, Ayvazov addressed his guests, 'Please do not consider it odd for a representative of a starving country to offer such a dinner. This can be excused by its purpose which is to remind you once more of our calamity-stricken compatriots. ${ }^{227}$ Ayvazov continued to talk about the disastrous aspects of the famine, but strangely also emphasized the recent history of the Crimean Tatars. He gave an account of the independence of the Crimea during the period of the Crimean Khanate, its destruction by tsarist Russia, the sufferings of the Crimean Tatars thereafter, the national awakening movement of the Crimean Tatars led by İsmail Bey Gaspiralı, the 'happy moment of the formation of the Crimean Tatar National Kurultay' [which had actually fought against, and was ultimately destroyed by the Bolsheviks!] and the chaotic period in the Crimea later. ${ }^{228}$ Obviously the speaker was hardly a typical Soviet official but rather a characteristic Crimean Tatar/Turkic nationalist, as Ayvazov indeed was. During the dinner other interesting topics were discussed. One of them was voiced by Abilov, about the convocation of a 'Congress of Eastern Peoples' in Anatolia, an idea which was current in some circles in Ankara. ${ }^{229}$

The Crimean administration attached a great deal of importance to the role of Ayvazov in Ankara. The Presidiums of the Central Executive Committee, Council of People's Commissars, and the Pomgol of the Crimean ASSR stated on 13 October 1922 that they had found the activities 
of the Crimean delegation in Ankara satisfactory. The Presidiums also applied to the Central Committee of Pomgol to prepare detailed accounts to be forwarded to the government and press in Ankara. They also decided to inform the KAYH in Ankara of their preference for the relief in cash. ${ }^{230}$

The second shipment of relief from Turkey was actually planned to be shipped to the Crimea in late June $1922,{ }^{231}$ yet for some reason it was postponed. ${ }^{232}$ It is likely that this delay had to do with the decision to include the Volga-Ural region in the relief plan too. In consequence, the shipment of Turkish famine aid could not be effected earlier than the second week of September 1922. Interestingly, it was at this very time that the armies of the Grand National Assembly executed and brilliantly concluded great offensive against the Greeks and liberated virtually all the lands in Anatolia that had previously been occupied by the Greek army. This victory deeply mobilized the Turkic Muslims of Soviet Russia. For example, in Sevastopol (Akyar) a large celebratory meeting was held by the local Crimean Tatars on the news of the Turkish victory and a message of congratulations was cabled to Mustafa Kemal Pasha via Semyon Aralov. ${ }^{233}$ The Central Spiritual Board of the Muslims of Inner Russia and Siberia also sent a telegram to the Turkish Embassy in Moscow appplauding the victory in the name of all Muslims of Russia. ${ }^{234}$

The relief materials, accompanied by two Red Crescent officials, namely İbrahim Hakk1 Bey and Süleyman Faik Bey, were unloaded at the port of Sevastopol on 18 September 1922.235 They consisted of 2,000 sacks of wheat flour, 1,756 cases of dry vegetables and canned consommé, of which 1,060 were earmarked for Kazan. Notwithstanding the polite welcome, trouble arose in Sevastopol and Akmescit about to whom and how the relief materials would be distributed. The Crimean Central Pomgol was not pleased to deliver them exclusively to the Crimean Tatars. ${ }^{236}$ The Red Crescent officials argued that the materials were sent by Anatolian Muslims to their co-religionists in the Crimea as a gift on the occasion of the Muslim religious Holiday of Sacrifice (Kurban Bayramı). ${ }^{237}$ Eventually, it was agreed by both the Red Crescent officials and the Crimean governmental bodies to disseminate the food to the Crimean Tatars through the Crimean Central Executive Committee while the process would be overseen by the Red Crescent. ${ }^{238}$

The Turkish officials prepared a distribution list for 15 districts, taking into consideration the degree of need and population of the localities. In this list, the Crimean Tatar teachers and the two important Crimean Tatar educational institutions, namely the Crimean Tatar Girls' Teacher's School and the Crimean Tatar Technicum in Totayköy, were not forgotten. ${ }^{239}$ In order to confirm the method of distribution in the Crimea as well as to 
arrange the delivery of the relief to Kazan, the Red Crescent officials travelled to Moscow. There, they were received by the Chairman of the AllRussian Central Executive Committee, Mikhail Kalinin. Thereafter, at the invitation of the Kazan Tatars, İbrahim Hakk1 Bey proceeded to Kazan, while Süleyman Faik Bey returned to the Crimea. The former was welcomed with extraordinary gratitude and respect in Kazan where he witnessed the arrival of the relief trunks. He went back to the Crimea on 12 November $1922 . .^{240}$ This was not the end of the relief work that the Turkish Red Crescent conducted in the Volga-Ural region. As had been planned, individual relief parcels were sent to the several hundred intellectuals and scholars through the ARA. ${ }^{241}$

In the Crimea, Red Crescent officials checked the distribution process of the relief effort by personally visiting most of the places hit by the famine. ${ }^{242}$ Although their task proceeded smoothly for the most part, in cases where government authorities preferred to send flour to places other than those indicated on the list, Turkish officials as well as certain Crimean Tatar dignitaries such as Veli İbraimov objected and the situation was rectified. ${ }^{243}$

The Crimean Central Pomgol sent a letter of thanks to the General Centre of the Red Crescent. Having stated that the two shipments of relief from Turkey had given great happiness and pleasure to starving Crimeans, it confirmed that relief materials would be distributed among the Muslim population in accord with the plan designed by the officials of the Red Crescent. The Pomgol also stressed that it was possible that within two months some 300,000 people might again fall victim to famine and therefore further relief would be very much appreciated by the Crimeans. ${ }^{24}$ Later, a similar message expressing the gratitude of the Crimeans was sent by the Crimean ASSR Central Executive Committee to the KAYH [the name of which had by then changed to URAMMH] on 7 October 1922. The Central Executive Committee expressed its gratitude that its call for help from Turkey in March 1922 was responded to in this way. Still, the Committee repeated that there were currently 350,000 needy and starving people in the Crimea, of which 210,000 were being fed by the Crimean Pomgol and 100,000 by the ARA; the remaining 40,000 were without any relief due to the demand for resources. Moreover, prospects for the forthcoming months and next year were not good either. Therefore, the Crimean Central Executive Committee urgently requested continuing relief from Turkey. ${ }^{245}$

There were other messages of gratitude and requests for further relief. One such letter came from Habibullah Temircan Odabaş and Osman Akçokraklı, two prominent figures of Crimean Tatar national awakening, renowned scholars, and the then Director and Chief Secretary of the Crimean Tatar Girls' Teachers' School [Kırım Tatar Darülmuallimâtı], 
respectively. Odabaş and Akçokraklı explained the significance of this relatively small but celebrated Crimean Tatar educational institution which, after long years of struggle during the tsarist period, was opened by the Crimean Tatar National Kurultay (or rather its organ, the Millî İdare) following the Russian Revolution. They were most grateful for the relief provided by the Red Crescent, but due to the fact that the school had to cover most of its costs from its own less than sufficient means, it was in dire need of further relief from the Red Crescent for the duration of the famine in the Crimea. A special allocation was also requested from the expected relief for the Crimean Tatar Obstetrics School which was functioning alongside the Girls' Teachers' School. ${ }^{246}$

Likewise, the representatives of the Volga-Ural Muslims also expressed their gratitude to the Red Crescent while requesting that the relief work continue for the future. Kadı Keşşâfüddin Tercümânî wrote similarly to the Red Crescent on 8 December 1922 and stated that all the canned food sent by the Red Crescent had been distributed to the Muslim orphanages in Moscow, Ufa, and Kazan. Yet there were still hundreds of thousands of starving and miserable Muslim children in the Volga-Ural region, where continued relief from the Red Crescent would be greatly needed. The Central Spiritual Board of the Muslims of Inner Russia and Siberia wanted to appoint Feyzullah Mehmed Feyzi Bey as the representative of the Central Spiritual Board in Istanbul and it was requested that his salary be paid by deducting it from would-be donations. As for a representative of the Red Crescent in Russia to oversee the correct distribution of the relief, a volunteer representative was found. ${ }^{247}$ Another expression of gratitude came from the All-Russian Muslim Clergymen Congress which was convened in Ufa and which adopted an open declaration thanking the Turkish Red Crescent on 25 June 1923. ${ }^{248}$

Apprehension in the Crimea and in the Volga-Ural region about the extension of the famine to 1923 was not totally unfounded. In the Volga basin, the worries about the repetition of the famine came to a gradual end only with the coming of spring, when the scenes of famine were confined to a few isolated pockets. ${ }^{249}$ In the Crimea during the winter of 1922-23, the grain stocks proved to be dangerously low and in February 1923 the Hessen fly destroyed a fifth to half of the winter crops. ${ }^{250}$ Only by summer $1923 \mathrm{did}$ the famine become a matter of the past. ${ }^{251}$ Indeed, its legacy was to last for a long time to come.

The Turkish Red Crescent could hardly meet requests for further relief as it was virtually overwhelmed. The huge destruction and enormous humanitarian need which emerged with the Great Offensive and its aftermath meant that the Red Crescent could only concentrate on domestic problems. Moreover, the mass population exchange between Turkey and 
Greece, that is, the exodus of all Greeks in Turkey to Greece (with the exception of those in Istanbul) and all Turks in Greece to Turkey (except for the Turks of Western Thrace) involved millions of people. The Red Crescent had to bear the brunt of the immediate burden of this tremendous task, and therefore was unable to send any relief to the Crimea or the Volga basin. When, in 1923, the Tatar Charitable Society voiced the need to send relief to the Crimea, the Red Crescent could ship only 500 suits of clothes. $^{252}$ It is also known that in September 1923, Yusuf Akçura, the famous historian and intellectual of Volga Tatar origin, personally requested support for a few individual Crimean Tatar refugees or immigrants, but apparently nothing came of it. ${ }^{253}$ This probably concluded the Turkish Red Crescent's, or rather Turkey's, relief effort for the victims of famine in Soviet Russia.

Apart from the victims of famine, the Turkish Red Crescent also helped other groups from the Soviet territories during this period. It offered help to many Azerbaijani refugees in Istanbul, ${ }^{254}$ and also provided relief for emigrants from Ajaria. ${ }^{255}$ Some 200 Christian Georgian refugees in Istanbul, mainly women and children who were deprived of any other help, were cared for by the Red Crescent. ${ }^{256}$ Certainly another huge humanitarian catastrophe of these years was that of hundreds of thousands of Russian refugees who had to flee from Russia after the establishment of Bolshevik rule, many of whom arrived in Istanbul in a miserable state. Given the existing extraordinary political and social problems which far exceeded its means, the Red Crescent was able to offer only modest relief to these hapless people. Even so, the Red Crescent co-operated with Western organizations that were then providing relief to the Russian refugees, allocating certain facilities for that purpose. ${ }^{257}$

In short, during the great famine in Soviet Russia, among many other foreign countries and organizations, Turkey also made its contribution to the relief efforts. The horrible stories coming from the famine-stricken Crimea and the Volga-Ural region, lands with large native Turkic Muslim populations struck a very sensitive cord in Turkey, notwithstanding the latter's own extraordinarily troubled situation. In the midst of a war of independence a very active and widespread relief campaign was conducted among the war-worn, poverty-stricken Anatolian people. It should not be thought that the famine relief of Anatolia was simply a gesture on the part of the Ankara government to impress Soviet Russia from whom it was desperately seeking material assistance. There is no evidence that it was anything other than a serious and spontaneous reaction of the Anatolian Muslims who were shocked to hear about the horrors of famine which their ethnic and religious brethren were experiencing. 
The amount of aid from Turkey was obviously by no means sufficient to alleviate the overall horrors of the famine in the Crimea and the Volga basin. It was actually dwarfed by the scale of relief coming from western countries, especially those flowing through the ARA during the same period. Nevertheless, Turkish relief did help significantly those individuals fortunate enough to receive it and who had otherwise little else to save themselves (after all, none of the domestic or foreign relief was adequate to feed and save all of the victims anyway). Still, the relief efforts of the Turkish people and the Grand National Assembly of Ankara were most meaningful, as they occurred at the very time Anatolia itself was going through one of the hardest times in its modern history.

\section{NOTES}

1. Harold H. Fisher, The Famine in Soviet Russia, 1919-1923 (New York, 1927), pp.496-500.

2. Benjamin Weissman, Herbert Hoover and Famine Relief to Soviet Russia: 1921-1923 (Stanford, 1974), p.5; Richard Pipes, Russia under the Bolshevik Regime (New York, 1995), p.411.

3. John Maynard, The Russian Peasant (New York, 1962), pp.185-6.

4. Fisher, pp.504-5; Weissman, pp.3-6; Pipes, pp.411-12.

5. Weissman, pp.4-6.

6. Benjamin Robertson, The Famine in Russia (London, no date [1922]), pp.4, 6.

7. Süleyman Rahimov, 'Golod osobenno svirepstvoval v derevnyakh ...', Gasirlar Avazı Ekho Vekov (Kazan), Nos.3/4 (1997), pp.113-14.

8. Ibid., p.115.

9. Weissman, pp.198-9.

10. Fisher, p.395.

11. Pipes, p.417.

12. Ibid., p.419.

13. Kozlov, 'Otchyot o deyatel'nosti rossiiskogo obshchestva Krasnogo Kresta v Tatrespublike', Gastrlar Avazl-Ekho Vekov (Kazan), Nos.3/4 (1997), p.132.

14. Andrei Yegorov, 'Ademner Tudırgan Afet (1921: Y1lg1 Açlık Facigas1)', Tulpar (Ufa), No.2 (Sept.-Oct. 1994), p.52.

15. Ibid.; Weissman, p.3.

16. Yegorov, pp.52-3; Weissman, p.7. For examples of the contemporary official reporting several individual cases of cannibalism, including those of family members, see (following Rahimov's article) Gasırlar Avazl-Ekho Vekov (Kazan), Nos.3/4 (1997), pp.118-21.

17. Yegorov, p.52.

18. Weissman, p.7.

19. Yegorov, p.52.

20. Fisher, p. 88

21. Rahimov, pp.115-16.

22. Weissman, p.86.

23. Abdullah Battal-Taymas, Kazanlı Türk Meşhurlarından Rizaeddin Fahreddinoğlu (Istanbul, 1958), pp.28-9.

24. Among those who received these parcels were such prominent figures as Rizaeddin Fahreddin, Musa Carullah Bigi, Keşşafüddin Tercümânî, Cemaleddin Velidî, Alimcan Barudî, Hadi Atlâsî, Muhlise Bûbî, Necib Asrî, Fatih Kerimî, Abdurrahman Ömer, Fatih Emirhan, Hasan 
Ata Abeșî, Muhiddin Kurbangali, Fatih Murtaza, and several others. These parcels were sent in the name of the Tatar community in Finland by Veli Ahmed Hekim, the Imam of the Helsinki mosque. The list of persons to whom the help would be sent was prepared by Abdulbari Battal (Abdullah Battal-Taymas), an intellectual from Kazan; ibid., pp.29 and 51-4.

25. Kozlov, p.136.

26. Charles Edmondson, 'An Inquiry into the Termination of Soviet Famine Relief Programmes and the Renewal of Grain Export, 1922-3', Soviet Studies, Vol. XXXIII, No.3 (July 1981), pp.371-2.

27. Ibid., pp.375-6. The acronym Posledgol stood for Tsentralnaya Komissiya po Bor'be's Posledstvyami Goloda (Central Commission for the Struggle against the Consequences of the Famine).

28. Fisher, p.276.

29. Ibid., p.278; Vyacheslav Georgievich Zarubin and Aleksandr Georgievich Zarubin, 'Golod v Krymu (1921-23)', Klio (Akmescit/Simferopol), Nos.1-4 (1995), p.34.

30. 'Doklad predsedatelya TsK Pomgola na vtoroi Vsekrymskoi Tatarskoi Bespartiinoi Konferentsii', Gosudarstvennyi Arkhiv Avtonomnoi Respubliki Krym (State Archives of the Crimean Autonomous Republic), hereafter cited as GAARK (Akmescit/Simferopol) fond R-151, opis' 1, delo 1, 1. 163.

31. Said, 'Eto vymiranie tseloi natsii', Zhizn' Natsional'nostei (Moscow), Nos.6-7 (12-13) (141-142) (14 April 1922), p.11; K. Sorin, 'V Krymu', Zhizn' Natsional'nostei, No.1 (7) (136) (25 Feb. 1922), p.9.

32. Fisher, p.278.

33. Zarubin and Zarubin, p.35.

34. Ibid.; Fisher, p.278.

35. Said, p.11; Zarubin and Zarubin, p.35. The first chairman of the Crimean Pomgol was A.I. Izrailovich, the Secretary of the Oblast Committee of the Russian Communist Party (Bolshevik). In mid-Feb. 1922, Yurii Gaven, Chairman of the Central Executive Committee of the Crimean Autonomous Soviet Socialist Republic, took over the chairmanship of the Crimean Pomgol too. His deputy was B.S. Shvedov. Among the Crimean Tatar members of the Crimean Central Committee of Pomgol were the famous poet and linguist Bekir Sttkı Çobanzâde, Ümer İbrahim, the People's Commissar of Agriculture, and Selim Memetov.

36. Zarubin and Zarubin, p.35.

37. 'O priznanii Krymskoi Avtonomnoi Respubliki golodaiushchim raionom', Biulleten' Tsentral'noi Komissii pomoshchi golodaiushchim VTsIK, Nos.5-7 (Feb.-April 1922), p.43. The decree bore the signatures of Mikhail Kalinin, Chairman of the All-Russian Central Executive Committee and Abel Yenukidze, Secretary of the All-Russian Central Executive Committee.

38. Viktor Yeremeevich Baranchenko, Gaven (Moscow, 1967), p.120. The Zarubins gave somewhat different death figures: Jan: 8.000, Feb: 14,413, March: 19,902, April: 12,753. They also admit, however, that the figures and the statistical data cited in the contemporary documents of that period were confusing as well as far from complete. Zarubin and Zarubin, p.35.

39. Said, p.11; 'Krymskaya respublika', Zhizn' Natsional'nostei, No.8 (14) (143) (26 April 1922), p.5.

40. Zarubin and Zarubin, p.35.

41. 'Krymskaya respublika' (note 39), p.5.

42. Said, p.11.

43. Baranchenko, p.120.

44. Maksut Arançı11, 'Maksut Arançılı'nın Hatıraları' (Memoirs of Maksut Arançı11), recorded 25 Dec. 1982, in Ankara, manuscript, in the possession of the author, p.3.

45. 'Memorandum on conditions in Crimea based on information furnished by Madame Zelinskaia, an Englishwoman, who has recently arrived from Sevastopol on the 27 March [1922]', Public Record Office (hereafter cited as PRO) (London), F.O. 371/8178; Zarubin and Zarubin, p.36; Baranchenko, p.120. 
46. Sorin, p.9.

47. 'Memorandum on conditions in Crimea ...' (note 45).

48. Baranchenko, p.125; Said, p.11; [Aynelhayat], Recai Sanay (ed.), Kızll Rusya'da Bir Türk Kadını (Istanbul, n.d.), p.82.

49. Baranchenko, p.120.

50. 'Svodka No.18 N.K.V.D. Krymskoi Respubliki', Gosudarstvennyi Arkhiv Rossiiskoi Federatsii (State Archives of the Russian Federation - hereafter cited as GARF) (Moscow), f. R-393, op.35, d. 589, 1. 252; P.N. Nadinskii, 'Bor'ba krymskoi partorganizatsii za vosstanovlenie narodnogo khozyaistva (1921-1925 gg.)', Bor'ba bol'shevikov za uprochenie sovetskoi vlasti, vosstanovlenie $i$ razvitie narodnogo khozyaistva Kryma (Akmescit/Simferopol, 1958), p.138.

51. Baranchenko, p.123

52. Ibid., p.120; Aranç1l1, p.3; Nadinskii, p.137.

53. Baranchenko, pp.125 and 128; 'Report sent to Dr Frick at Berlin from Monsieur Yavoroff, member of International Russian Relief Committee, 21 July 1922', PRO (London), F.O. $371 / 8150$

54. Zarubin and Zarubin, p.38

55. Nadinskii, p.137.

56. Veli İbraimov, 'Pyat' let Sovetskoi vlasti v Krymu', Ves' Krym. 1920-1925 (Akmescit/Simferopol, 1926), p.vi; Baranchenko, p.128.

57. İbraimov, p.vi. Veli İbraimov, Chairman of the Central Executive Committee of the Crimean Autonomous Soviet Socialist Republic after 1923, was to state in 1927 that the number of Crimean Tatars who lost their lives during the 1921-22 famine was around 76,000 , Zarubin and Zarubin, p.38.

58. Zarubin and Zarubin, p.38.

59. Such was the degree of destruction to Crimean agriculture in 1922 (1916=100 per cent): entire sowing area, 24 per cent; amount of grain per person, 25.4 per cent; working horses, 36.1 per cent; working cattle, 36 per cent; cows, 78 per cent; sheep, 62.4 per cent; pigs, 10.4 per cent; İbraimov, p.vi.

60. Nadinskii, p.137; Baranchenko, p.128.

61. Baranchenko, p.121.

62. K., 'Vtoraya sessiya Krymtsik'a', Zhizn' Natsional'nostei, No.5 (11) (140) (1 April 1922), p. 8

63. Said, p.11.

64. Baranchenko, p.122

65. Arançıll, p.2.

66. Baranchenko, pp.121 and 123. For example, on 18 July 1922, a Norwegian ship brought 5,000 poods of rye and wheat from Argentina in the name of the Ukrainian Foreign Trade (Vneshtorg) organization. 'Kırım Limanlarında', Yeni Dünya (Akmescit/Simferopol), 25 July 1922.

67. Baranchenko, p.120.

68. K., p.8.

69. Baranchenko, pp.120-21.

70. Said, p.11

71. 'Krym', Biulleten' Tsentral'noi Komissii pomoshchi golodaiushchim VTsIK (Moscow), Nos.5-7 (Feb.-April 1922), p.72.

72. Nadinskii, p.137.

73. Zarubin and Zarubin, p.37.

74. Baranchenko, p.125. Actually, living conditions of scholars and scientists in Crimea were miserable too. A special relief committee for them was founded by a group of professors in the Tolstoy Institute in Sevastopol, headed by A. Shcherbak. 'Kırım Açlarına Muavenet', Vakit (Istanbul), 24 May 1922.

75. 'Krym', Biulleten' Tsentral'noi Komissii pomoshchi golodaiushchim VTsIK, Nos.5-7 (Feb.-April 1922), p.72; Baranchenko, pp.122 and 124. 
76. Said, p.11.

77. 'Krym', Biulleten' Tsentral'noi Komissii pomoshchi golodaiushchim VTsIK (Moscow), Nos.5-7 (Feb.-April 1922), p.85.

78. Zarubin and Zarubin, p.35.

79. Baranchenko, p.124.

80. Nadinskii, p. 136 .

81. This figure was given by an official of the Dr Nansen organization. 'Kırım'da Açlık', Vakıt (Istanbul), 21 July 1922.

82. Zarubin and Zarubin, p. 35 .

83. Ibid., p.38.

84. Ibid., p.37.

85. Nadinskii, p.136.

86. Zarubin and Zarubin, p.37.

87. 'Krymskaya respublika' (note 39), p.5.

88. 'Rezoliutsiya po dokladu tov. Gavena', GAARK (Akmescit/Simferopol), fond R-151, opis' 1 , delo $1,1.165$ and the obverse.

89. Ibid.

90. 'Krymskaya respublika' (note 39), p.5.

91. Fisher, p.279.

92. Ibid., pp.279-80.

93. 'Missiya miloserdiya. Pis'mo direktora ARA v Krymu Mistera Foksa', Tavricheskie Vedomosti (Akmescit/Simferopol), No.10 (March 1992). As of 1 September 1922, the ARA was feeding 117,276 adults, 42,293 children, and 3,100 sick in the Crimea. See Zarubin and Zarubin, p.37.

94. Fisher, p.280.

95. Baranchenko, p.121.

96. 'International Committee for Russian Relief. High Commissariat of Dr Nansen. Information No.30. Geneva, August, 30th, 1922', PRO (London), F.O. 371/8150, p.30.

97. Baranchenko, p.122.

98. Zarubin and Zarubin, p.37.

99. 'Protokol No.14. Zasedaniya Prezidiuma Tsentral'nogo Ispolnitel'nogo Komiteta Kr. A.S.S.R. Fevralya 2-go dnya 1922 goda', GARF, f. R-393, op.35, d. 589, 1. 5.

100. K., pp.7-8. According to one source, it was Osman Derenayırlı who proposed to send such a delegation to Turkey. Vladimir Mikhailovich Broshevan and Aleksandr Andreevich Formanchuk, Krymskaya respublika: god 1921-i (Akmescit/Simferopol, 1992), p.75.

101. 'Vtoraya sessiya Kr. TsIK'a', GARF, f. R-393, op.28, d. 362, 1. 525.

102. Both Ayvazov and Nedim later became victims of the Stalinist repressions and were shot in 1938.

103. For the activities of Hasan Sabri Ayvazov prior to 1918, see, Edige Kırımal, Der nationale Kampf der Krimtürken (Emstedten/Westfalen, 1952) and Hakan Kirıml, National Movements and National Identity among the Crimean Tatars (1905-1916) (Leiden, 1996).

104. 'Obrashchenie II-i Sessii Krymskogo Tsentral'nogo Ispolnitel'nogo Komiteta Sovetov k Velikomu Natsional'nomu Sobraniiu v Angore', GARF, f. R-393, op.28, d. 362, 1. 529.

105. Atatürk'ü̈n Millî Dış Politikası, Vol.I (Ankara, 1981), p.353.

106. Ibid., p. 355 .

107. Dokumenty vneshnei politiki SSSR, Vol.IV (Moscow, 1960), p.356. Natsarenus expressed his gratitude, in the name of his government and the Russian people, to Yusuf Kemal Bey on the same day; Ibid., pp.355-6.

108. 'From the People's Commissariat for Foreign Affairs to Ali Fuad Pasha, the Ambassador of Turkey in Moscow, 27 Sept. 1921', Arkhiv Vneishnei Politiki Rossiiskoi Federatsii (Foreign Policy Archives of the Russian Federation) fond 132, opis' 4, kor. 2, papka 4, 1. 49.

109. Said Halimov, 'Krymskaya Avtonomnaya Respublika', Zhizn' Natsional'nostei (Moscow), No.1 (Jan. 1923), p.120.

110. 'Kırım'da Hayat-1 Umumiyye ve Müslümanlar', Vakat (Istanbul), 16 Nov. 1921.

111. 'Kırım İlân-1 İstiklâl Etti', Tevhîd-i Efkâr, 5 Jan. 1922; 'Kırım'ın İstiklâli', İkdam 
(Istanbul), 7 Jan. 1922; 'Türklük Yeni Bir İstiklâl Daha Selâmlıyor', Anadolu'da Yeni Gün (Ankara), 9 Jan. 1922; 'Müstakil Kırım', Hakimiyet-i Milliyye (Ankara), 9 Jan. 1922; 'Kardaş Kırım Cumhuriyeti'nin Hududu', Hakimiyet-i Milliyye (Ankara), 27 Jan. 1922.

112. 'Kırım'dan Ankara'ya Heyet', Vakıt (Istanbul), 12 Feb. 1922.

113. 'Asya İslâmları ve Ankara', İkdam (Istanbul), 13 March 1922.

114. 'Tatar Cemiyet-i Hayriyyesi'nin Millete Beyannâmesi', Birinci Gök Kitap. Hakkn Sesleri (Istanbul, 1919), p.147.

115. 'Kırımlılara Yardım', Vakıt (Istanbul), 1 April 1922.

116. 'Hilâl-i Ahmer'in Kırım Müslümanlarına Muaveneti', Osmanlı Hilâl-i Ahmer Mecmuası (Istanbul), No.8 (15 April 1922), p.179. In this official organ of the Ottoman Red Crescent Society, the name of the Tatar Charitable Society was cited erroneously as the 'Crimean Charitable Society'. For a full citation of the same text, see 'Kırım Müslümanlarına Muavenet', Peyâm-ı Sabah (Istanbul), 22 April 1922.

117. 'From the General Centre of the Red Crescent Society to the Red Crescent Delegation in Ankara, 10 April 1922', Türkiye Kızllay Derneği Merkez Arşivi (Archives of the Turkish Red Crescent Society, hereafter cited as TKDMA) (Etimesgut, Ankara), dosya no.331$5 / 1922$.

118. 'Kırım Açları İçin Türk ve Müslüman Dünyasına Bir Müracaat', İkdam (Istanbul), 13 April 1922.

119. 'From the General Centre of the Tatar Charitable Society to the Chairmanship of the Ottoman Red Crescent Society, 30 April 1922', TKDMA, dosya no.331-5/1922.

120. 'Cafer Seydahmed Bey', Vakat (Istanbul), 8 April 1922.

121. 'Kırım'daki Dindaş ve Milletdaşlarımızın Hâli', İkdam (Istanbul), 10 April 1922; 'Kırım Hariciye ve Harbiye Nâzırı Cafer Seydahmed Bey’le Bir Hasbıhâl', Tevhîd-i Efkâr (Istanbul), 10 April 1922.

122. 'Kırım'daki Dindaş ve Milletdafllarımızın Hâli', İkdam (Istanbul), 10 April 1922.

123. 'Seyid Cafer Bey Şehrimizde', Hakimiyet-i Milliyye (Ankara), 20 April 1922; Ahmed Hidayet, 'Bir Kırım Murahhası Ankara'da', Ik kdam (Istanbul), 22 April 1922.

124. 'Kırım Hariciye ve Harbiye Nâzırı Cafer Seydahmed Bey'le Bir Hasbıhâl', Tevhîd-i Efkâr, 10 April 1922

125. 'Kırım Mümessili Sabri Ayvazov Yoldaş Şehrimizde', Anadolu'da Yeni Gün (Ankara), 18 April 1922; 'Kırım Murahhası Ankara'da', Açık Söz (Kastamonu), 19 April 1922.

126. The simultaneous presence of these two figures in Ankara did not escape the attention of the press. The Istanbul daily İkdam wrote, 'though they belong to, and serve, two antagonistic camps, they rushed into the struggle against the present catastrophe of famine in their country as brothers in arms'. 'Kırım Açları', İkdam (Istanbul), 1 May 1922. Actually, they were indeed 'brothers in arms' and always remained so, although under the circumstances they could not admit it then.

127. 'Kırım Mümessili Sabri Ayvazov Yoldaş Şehrimizde', Anadolu'da Yeni Gün (Ankara), 18 April 1922.

128. 'Kırım Murahhası Cafer Bey', İkdam (Istanbul), 17 May 1922.

129. İbrahim Otar, 'Cafer Seydahmet Kırımer', Emel (Ankara), No.1 (Nov. 1960), s.24.

130. Among others, in the capacity of 'the President and Delegate of the Crimean Tatar Parliament' he applied to the President of the Egyptian Delegation at the Lausanne Conference asking for famine aid to the Crimea through the Turkish Red Crescent on 27 Nov. 1922. 'From Cafer Seydahmet to the President of the Egyptian Delegation in the Lausanne Conference, 27 November 1922', Private Archives of İsmail Otar (Istanbul).

131. 'Konferans', Hakimiyet-i Milliyye (Ankara), 20 April 1922; 'Dünkü Konferans', Hakimiyet-i Milliyye (Ankara), 21 April 1922.

132. 'Zavallı Kırım!', Hakimiyet-i Milliyye (Ankara), 24 April 1922.

133. The members of the committee included Celâl Bey [Bayar] (deputy of Saruhan, future President of the Republic of Turkey), Adnan [Adıvar] (deputy of Istanbul), Tevfik Rüşdü Bey [Aras] (deputy of Menteşe, future Minister of Foreign Affairs), Numan Usta (deputy of Istanbul, of Crimean Tatar origin and a workers' leader), Fuad Bey [Umay] (deputy of Bolu), and Ağaoğlu Ahmed [Agayev/Ağaoğlu] (General Director of Press, of Azerbaijani 
origin and previously a prominent intellectual figure among the Azerbaijani Turks). 'Dünkü Konferans', Hakimiyet-i Milliyye (Ankara), 21 April 1922.

134. 'Kırım Açları İçin Muavenet Talebi', Vakut (Istanbul), 22 April 1922.

135. The members of the Central Relief Committee for the Starving in the Crimea (KAYH) were Refet Pasha [Bele] (Chairman of the committee, General), Tevfik Rüsşü Bey [Aras] (deputy of Menteșe), Mahmud Esad Bey [Bozkurt] (deputy of İzmir), Dr Ömer Lütfi (an official of the Red Crescent), Dr Fuad (General Secretary of the Society for the Protection of Children), Numan Usta (deputy of Istanbul, of Crimean Tatar origin), Hacı Veli Efendi [Bayraktar] (deputy of Eskișehir, of Crimean Tatar origin). The local sub-committee consisted of Abdülkadir Bey (Governor of Ankara), the Mufti of Ankara, Bulgurluzâde Mehmed Efendi (a local notable), Attarzâde Rasim Efendi (a local notable), Şemseddin Efendi [Bayramoğlu] (deputy of Ankara, Ali Bey (Mayor of Ankara), Kınacızâde Şâkir Efendi [Kınac1] (deputy of Ankara), Necati Bey [Kurtuluş] (deputy of Bursa), Hatifzâde Mehmed Efendi (a local notable). Apart from these names, Osman Bey [Özgen] (deputy of Lazistan), İsmail Şükrü Bey [Çelikalay] (deputy of Karahisar-1 Sâhib), Yahya Galip Bey [Karg1] (deputy of Kırşehir), Rıza Bey [Silsüpür] (deputy of Kırşehir) and Nâzım Bey (exgovernor of Harput) were to assist in the work of both committees. 'Kırım'a Muavenet', Hakimiyet-i Milliyye (Ankara), 25 April 1922; 'Kırım Açlıktan Kırılıyor, Mahvoluyor', Anadolu'da Yeni Gün (Ankara), 25 April 1922.

136. 'Zavallı Kırım!', Hakimiyet-i Milliyye (Ankara), 24 April 1922; 'Açlığın ve Ölümün Tehdidindeki Kardeşlerimiz!', Anadolu'da Yeni Gün (Ankara), 23 April 1922; 'Kırım'daki Açlar Hakkında Ankara'da Verilen Bir Konferans', İkdam (Istanbul), 4 May 1922. 'Kırım'daki Açlar Hakkında Ankara'da Verilen Bir Konferans', Güzel Trabzon (Trabzon), 9 May 1922; 'Kırım'a Muavenet', Hakimiyet-i Milliyye (Ankara), 25 April 1922; 'Kırım Açlıktan Kırılıyor, Mahvoluyor', Anadolu'da Yeni Gün (Ankara), 25 April 1922; Kırım’da Kaht ve Açlık', Babalık (Konya), 12 May 1922.

137. 'Zavallı Kirım!', Hakimiyet-i Milliyye (Ankara), 24 April 1922.

138. 'From Refet Pasha, the Chairman of the KAYH to the Ankara Delegation of the Red Crescent Society, 26 April 1922', TKDMA, dosya no.331-5/1922; 'Kırım'daki Ac Kardeşlerimize Yardım İçin', Anadolu'da Yeni Gün (Ankara), 27 April 1922.

139. 'Kırım'a Yardım', Hakimiyet-i Milliyye (Ankara), 26 April 1922; 'Kırım Muhtâcînine Muavenet', Vakıt, 27 April 1922; 'Kırım Açlarına Yardım Heyeti', Hakimiyet-i Milliyye (Ankara), 27 April 1922; 'Kırım Muhtâcîni Menfaatine Müsamere', Hakimiyet-i Milliyye (Ankara), 27 April 1922; 'Kırım Muhtâcînine Muavenet', Açık Söz (Kastamonu), 27 April 1922.

140. 'Kırım'daki Aç Kardeşlerimize Yardım İçin', Anadolu'da Yeni Gün (Ankara), 27 April 1922.

141. 'Kırım Açlarına Yardım Heyeti'nin Beyannamesidir', Anadolu'da Yeni Gün (Ankara), 1 May 1922; 'Kırım Açları İçin', İkdam (Istanbul), 11 May 1922.

142. 'Matbuat Cemiyeti’nin Tamimi', Anadolu'da Yeni Gün (Ankara), 1 May 1922; 'Kırım Açlarına Yardım', Açık Söz (Kastamonu), 4 May 1922; 'Kırım Açlarına Muavenet', Vakıt (Istanbul), 5 May 1922.

143. For a few characteristic examples of such news items and interviews, full of horrible accounts of the famine, see 'Kırım'da Açlık', Vakıt (Istanbul), 23 April 1922; 'Açlara Yardım İ İin', Anadolu'da Yeni Gün, 9 May 1922; 'Kırım'da Açlık Şiddetleniyor', Vakit (Istanbul), 19 May 1922; 'Kırım'da Açlık Ne Derecededir?', İkdam (Istanbul), 9 June 1922.

144. Falih Rıfk1 [Atay], 'Sesleri Olmayan Mustaribler', Akşam (Istanbul), 24 May 1922.

145. İsmail Hakkı, 'Kırım Açlarına Yardım', Açık Söz (Kastamonu), 17 May 1922.

146. Hakimiyet-i Milliyye of Ankara carried a banner with the following words on 10, 12, 15, 24, 26, and 28 May 1922: 'Do not forget the starving Crimeans. Send your donations to the Red Crescent cashiers.' Baballk in Konya carried the following banner throughout 15-18, 21-24, 26, 28 May, and 8 June 1922: 'Relief to the Crimeans is a duty for every Turk and Muslim. Just think that our helpless brothers in the Crimea have fallen into such a desperate and grievous situation that they are compelled to eat human flesh.' 
147. Mesut Çapa, 'Anadolu'dan Kırım'a Yardım ve Yusuf Akçura'nın Bir Mektubu', Türk Kültürü (Ankara), No.359 (March 1993), p.155.

148. 'Lozan Türk Yurdu Muharrerât ve Zabt-1 Sâbık Defteri', manuscript, Türk Tarih Kurumu Arşivi (Archives of the Turkish Historical Society), No.Y/653, the records of the sessions on 12 June 1922 and 9 October 1922. Cafer Seydahmet was a member of the Lausanne Türk Yurdu (Turkish/Turkic Homeland) society and he made speeches about the famine in Russia (courtesy of Mehmet Şahingöz).

149. 'Kırım İçin', Hakimiyet-i Milliyye (Ankara), 26 June 1922.

150. 'Fas İslâmlarının Kırım Açlarına Muaveneti', Vakıt (Istanbul), 17 May 1922.

151. 'Kırım Muhtâcînine Muavenet', Vakıt (Istanbul), 27 April 1922; 'Kırım Açlarına Yardım Heyeti', Hakimiyet-i Milliyye (Ankara), 27 April 1922; 'Kırım Mültecilerine Muavenet', Baballk (Konya), 27 April 1922.

152. TBMM Zabit Ceridesi, Vol.18, Devre: 1, Íctima Senesi:3 (Ankara, 1959), p.480

153. 'From the Minister of Health and Social Welfare to the Ankara Delegation of the Red Crescent Society, 29 March 1922' and 'From the Ankara Delegation of the Red Crescent Society to the Commander of the Eastern Front, 29 March 1922' TKDMA, dosya no.3315/1922; TBMM Zabit Ceridesi, Vol.18, Devre: 1, İctima Senesi:3 (Ankara, 1959), p.480.

154. TBMM Zabit Ceridesi, Vol.18, Devre: 1, İctima Senesi:3 (Ankara, 1959), p.479.

155. Ibid., p. 480 .

156. Ibid., pp.480-82. Among the members elected to this special commission were Suat Bey [Soyer] (deputy of Kastamonu) and Mehmet Salih Efendi [Yeşiloğlu] (deputy of Erzurum). TBMM Zabit Ceridesi, Vol.19, Devre: 1, Íctima Senesi:3 (Ankara, 1959), p.104.

157. TBMM Zabit Ceridesi, Vol.19, Devre: 1, İctima Senesi:3 (Ankara, 1959), p.449.

158. Ibid., p. 40 .

159. İsmail Suphi Soysallı, 'Rusya Açlarına Muavenet Hakkında Bir Fikir', Hakimiyet-i Milliyye (Ankara), 25 April 1922.

160. 'Mebus-u Muhterem İsmail Soysallı Beyefendi'nin Mektubu Münasebetiyle', Hakimiyet-i Milliyye (Ankara), 27 April 1922.

161. 'Protokol No.35 Zasedaniya Prezidiuma TsK Pomgola 9 Maya 1922 goda', GAARK, fond R-652/1922, delo 59, 1. 126 .

162. I.S. Chirva (ed.), Ocherki po istorii Kryma, Part III, Krym v period sotsialisticheskogo stroitel'stva (1921-1941 gg.) (Akmescit/Simferopol, 1964), p.41. These allegations are simply incorrect, since there is not only no evidence indicating the approval of Ayvazov or Mahmut Nedim to the proposal but, as stated above, they were not enthusiastic about it at all, to say the least. Moreover, in the very same document which the author (Chirva ?) cites to prove his claim (see note 161) it is also apparent that the Crimean Pomgol approved the idea, and it gives no indication whatsoever that the Soviet government stopped its application.

163. 'Kırımlı Beş Yüz Bedbaht Mülteci', İkdam (Istanbul), 23 May 1922.

164. 'Kurım Muhacirleri', Hakimiyet-i Milliyye (Ankara), 25 May 1922.

165. 'Trabzon'da Kırım Mültecileri', Vakıt (Istanbul), 16 May 1922.

166. Until at least September 1922 (possibly until much later), the only financial support the Turkish General Consulate in Batumi received to deal with the refugees was the 1,000 Turkish liras sent by the Red Crescent on 1 June 1922. 'From the Ministry of Foreign Affairs to the Ankara Delegation of the Red Crescent, 18/19 June 1922' and 'From the Acting Consul General of Batumi to the Ankara Delegation of the Red Crescent, 9 Sept. 1922', TKDMA, dosya no. 331-5/1922.

167. Many of these refugees were settled in what was left of the former houses of the Molokans who had previously emigrated from the Kars and Ardahan districts to Russia. The refugees were living there in total penury and destitution. The Eastern Army which seemed to be the only authority dealing with their problems desperately asked for urgent aid in food, cloth, seed wheat, and domestic animals for this people. 'From the Deputy Commander of the Eastern Front to the Ankara Delegation of the Red Crescent, 26 Feb. 1923', TKDMA (Etimesgut, Ankara), dosya no. 331-5/1922.

168. 'Sokhranenie prava grazhdanstva RSFSR', Pravda (Moscow), 26 Aug. 1922. This 
resolution attracted the attention of the US diplomats too. 'From Evan E. Young, the Commissioner of the United States in Riga, to the Secretary of State, 28 Sept. 1922', US National Archives (Washington, DC), General Records of the Department of State, Political Relations between Russia and other States, 1910-29, No.2769.

169. Veli Necdet Bey, a Turkish official who visited the Crimea in June 1922, confirmed the presence of thousands of Crimean Tatars who were very eager to go to Turkey. 'Ukrayna'da Muahedelerin Teatisi Merasimi', Ikkdam (Istanbul), 26 Aug. 1922.

170. 'Kırım'da Açlık Şiddetleniyor', Vakat (Istanbul), 19 May 1922.

171. 'Kırım Muhtâcîni', Hakimiyet-i Milliyye (Ankara), 11 May 1922; 'Kırım ve Yerli Muhtaçlara Yardım', Hakimiyet-i Milliyye (Ankara), 22 May 1922.

172. 'Kırım Muhacirleri', Anadolu'da Yeni Gün (Ankara), 19 May 1922; 'Kırım Muhacirleri', Hakimiyet-i Milliyye (Ankara), 25 May 1922. A special commission, composed of Fuad Bey (the Director of Health of Tokat), Remzi Bey (engineer), and Galip Bey (agriculturist), was in charge of the settlement of the Crimean refugees arriving in Samsun. 'Kırım Mültecilerinin Kabulü', Hakimiyet-i Milliyye (Ankara), 16 June 1922.

173. 'Trabzon'da Kırım Mültecileri', Vakıt (Istanbul), 16 May 1922.

174. T.C. Başbakanlık Cumhuriyet Arşivi (Republican Archives of the Turkish Prime Ministry, hereafter cited as BCA) (Ankara), Toprak İskân Genel Müdürlüğü Fonu, No.272.79/ 72.1.6.

175. Nedim İpek, Mübadele ve Samsun (Ankara, 2000), p.123. Government aid was obviously insufficient to cover the needs of the refugees who were in a miserable situation. Some of the refugees were fortunate to be helped out by the charity of locals. For instance, in Tepecik, Yusuf Efendi, son of an earlier Crimean Tatar immigrant, donated plough animals, grain, and seed wheat to the refugees. He also built the irrigational system of the village and paid the salary of the teacher for the refugee children. İpek, p.51.

176. 'The Decree of the Cabinet of Ministers, 17 May 1922', BCA, Bakanlar Kurulu Kararları Fonu, No.030.18.1.1/5.16.15.

177. 'The Decree of the Cabinet of Ministers, 24 August 1922', BCA, Bakanlar Kurulu Kararları Fonu, No.030.18.1.1/5.25.10.

178. TBMM Zabut Ceridesi, Vol.24, Devre: I, İctima Senesi: 3 (Ankara, 1960), p.158.

179. Baballk exhorted its readers to give their alms of fitr for the benefit of the starving Crimeans. Many people from Konya and the surrounding towns did so and they were collected, together with other donations, and sent to Ankara by Baballk. Ahmet Avanas, Milli Mücadelede Konya (Ankara, 1998), p.254. Ahali was collecting donations in its editorial office in Samsun. 'Kırım Açlarına Yardım', Anadolu'da Yeni Gün (Ankara), 18 May 1922.

180. The Giresun Sports Training Centre (Idman Yurdu) organized such a performance in Giresun. 'Kırımlılara Yardım', Babalık (Konya), 16 June 1922.

181. 'Polatlı'da Kırım İânesi', Hakimiyet-i Milliyye (Ankara), 4 June 1922.

182. A girls' school in Ordu organized an exhibition where a variety of handicrafts and artistic works of the students were displayed and sold for the benefit of the starving Crimeans. 'Kırım Muhtâcîni Menfaatine Sergi', Hakimiyet-i Milliyye (Ankara), 1 June 1922.

183. 'Erciyes'de Kırımlılara Yardım', Hakimiyet-i Milliyye (Ankara), 7 June 1922.

184. 'Rizelilerin Kırım İânesi', Hakimiyet-i Milliyye (Ankara), 8 June 1922.

185. 'The Protocol of the KAYH within the Ministry of Religion, 18 Sept. 1922', BCA, Diyanet İșleri Reisliği Fonu, No.051/7.64.32.

186. The personnel of the Ankara Police Directorate collected donations among themselves. 'Polislerimiz ve Kırım İânesi', Hakimiyet-i Milliyye (Ankara), 21 June 1922.

187. 'From Colonel Celil, Commander of the 11th Division to the Ankara Delegation of the Red Crescent, 25 May 1922', and 'From the Commander of the 41st Division, 16th Regiment, to the Ankara Delegation of the Red Crescent, 29 May 1922', TKDMA, dosya no.3315/1922; 'Kırım İânesi', Babalık (Konya), 14 June 1922.

188. The personnel of the Ankara Post Office and all workers of the Keskin factory donated a day's wages. 'Alenî Teșekkür', Anadolu'da Yeni Gün (Ankara), 12 May 1922. The workers 
of the arms industry donated a day's wage in Kırıkkale. 'Kırım Açlıktan Kırılıyor, Mahvoluyor', Anadolu'da Yeni Gün (Ankara), 25 April 1922. All journalists, editors, printers, proofreaders, and other workers of Anadolu'da Yeni Gün donated a day's wage. 'Kırım Açlarına Yardım İçin Yeni Gün Amelesinin Kararı', Anadolu'da Yeni Gün (Ankara), 26 April 1922. Several government officials donated five per cent of their salaries. 'Kırımlılara Yardım', Hakimiyet-i Milliyye (Ankara), 28 April 1922.

189. For the correspondence from the local relief committees of Adapazar1, Bolu, Zonguldak, Ertuğrul, Gölpazarı, Mihalgazi, Osmaneli, Çan, Alâiyye, Burdur, Sandıklı, Beypazarı, Sincan, Corum, Sungurlu, Zârâ, Harput, Maden, Gümüşhane, Sarkî Karahisar, Yümni/Malatya, Bitlis, Siirt, Pervari, Siverek, and Diyarbekir to the Red Crescent about the donations collected there, see, TKDMA, dosya no. 331-5/1922. For the rest of the cities and towns where donations were collected, see, for Artvin: 'Kırım Açlarına Yardım Heyeti', Yeşil Yuva (Artvin), 1 Aug. 1922; Çapa, p.155; for Konya: 'Kırım Mültecilerine Yardım', Babalık (Konya), 8 June 1922; 'Kırım Açlarına Muavenet Komisyonu', Babalık (Konya), 13 Aug. 1922; 'Kırım İânesi', Hakimiyet-i Milliyye (Ankara), 14 June 1922; 'Kırım Îânesi', Hakimiyet-i Milliyye, 15 June 1922; for Mersin: 'Mersin'de Kırım Açları İçin', Anadolu'da Yeni Gün (Ankara), 4 May 1922; 'Kırım Muhtâcîni İçin', Anadolu'da Yeni Gün (Ankara), 9 June 1922; for Elaziz: 'Kırım İçin', Hakimiyet-i Milliyye (Ankara), 26 June 1922; for Ordu: 'Kırımlılara Mühim Bir İâne', Hakimiyet-i Milliyye (Ankara), 23 June 1922; for Zonguldak: 'Kırım Iânesi', Hakimiyet-i Milliyye (Ankara), 15 June 1922; for Eskişehir, Kozan, Seyhan, Alâiyye, Anamur: 'Kırım İânesi', Hakimiyet-i Milliyye (Ankara), 15 June 1922; for Polatlı: 'Kırım Iânesi', Hakimiyet-i Milliyye (Ankara), 15 June 1922; 'Polatlı'da Kırım İânesi', Hakimiyet-i Milliyye (Ankara), 4 June 1922; for Samsun: 'Kırım Açlarına Yardım', Anadolu'da Yeni Gün (Ankara), 18 May 1922; for Ordu: 'Kırım Muhtâcîni Menfaatine Sergi', Hakimiyet-i Milliyye (Ankara), 1 June 1922; Türkiye Hilâl-i Ahmer Cemiyeti Merkez-i Umumîsi Tarafindan 1339 Senesi Hilâl-i Ahmer Meclis-i Umumîisi'ne Takdim Edilen (1335-1338) Dört Senelik Devreye Ait Rapor (Istanbul, 1923), p.148; for Giresun: 'Kırımlılara Yardım', Babalık (Konya), 16 June 1922; for Rize: 'Rizelilerin Kırım İânesi', Hakimiyet-i Milliyye (Ankara), 8 June 1922; for Kayseri: 'Erciyes'de Kırımlılara Yardım', Hakimiyet-i Milliyye (Ankara), 7 June 1922.

190. Semyon İ. Aralov, Bir Sovyet Diplomatınin Türkiye Hattralarl (Istanbul, 1967), p.114.

191. Bülent Gökay, A Clash of Empires: Turkey between Russian Bolshevism and British Imperialism, 1918-1923 (London, 1997), p.120.

192. For an account of this episode by its primary actors, see Ali Fuat Cebesoy, Moskova Hattralarl (21/11/1920 - 2/6/1922) (Istanbul, 1955), pp.329-48.

193. Baranchenko, p.125.

194. 'From Mahmud Esad [Bozkurt], the General Secretary of the KAYH to the Ankara Delegation of the Red Crescent, 9 May 1922', TKDMA, dosya no.331-5/1922.

195. 'From Mahmud Esad [Bozkurt], the General Secretary of the KAYH to the Ankara Delegation of the Red Crescent, 16 May 1922', TKDMA, dosya no.331-5/1922.

196. 'Kırım'a Giden Yardım Heyetimiz', Anadolu'da Yeni Gün (Ankara), 24 May 1922; 'Kırım Açları İçin', İkdam (Istanbul), 25 Aug. 1922.

197. 'Kırım'daki Aç Dindaşlarımıza Muavenet', İkdam (Istanbul), 24 July 1922; 'Kırım'ın Sefaleti Son Derecededir', İkdam (Istanbul), 17 June 1922.

198. 'Kırım Ne Haldedir?', Íkdam (Istanbul), 20 June 1922; 'Kırım Açları İçin', İkdam, 25 Aug. 1922; 'Kırım'daki Kardeşlerin Selâmı', Vakıt (Istanbul), 26 Aug. 1922.

199. 'Ukrayna'da Muahedelerin Teatisi Merasimi', İkdam (Istanbul), 26 Aug. 1922. It is also known that another Turkish diplomat, the General Consul Sabri Bey, arrived in Yalta by a Turkish gunboat to deal with the problems of the Turkish subjects on 18 July 1922 . 'Türkiye Başşehbenderi', Yeni Dünya (Istanbul), 25 July 1922.

200. A news item in Yeni Dünya, the leading Turkish/Crimean Tatar newspaper in Akmescit, read that the local Pomgol of the Yalta okrug had received from the Crimean Central Pomgol 150 sacks of Red Crescent's flour which fell to the share of the Muslims in the okrug on 18 July 1922. 'Hilâl-İ Ahmer'in Hediyesi', Yeni Dünya (Akmescit/Simferopol), 25 July 1922. 
201. The name of the Central Spiritual Board of the Muslims of Inner Russia and Siberia is in Russian Tsentral'noe Dukhovnoe Upravlenie Musul'man Vnutrennei Rossii i Sibiri, and in Turkic (Tatar), İçki Rusiye ve Sibir Müsülmanları Diniyye Nezâreti.

202. 'Polozhenie o poryadke deyatel'nosti tsentral'nogo upravleniya musul'man vnutrennei Rossii i Sibiri po okazaniiu pomoshchi golodaiushchim', Biulleten Tsentral'noi Komissii Pomoshchi Golodaiushchim VTsIK (Moscow), Nos.5-7 (Feb.-April 1922), p.42; Ibid.,'Instruktsiya o poryadke sbora pozhertvovanii i otchyotnosti organov Pomgola pri Tsentral'nom Upravlenii musul'man RSFSR', pp.42-3; ibid.,'Instruktsiya, ustanavlivaiushchaya poryadok sbora pozhertvovanii sredi veruiushchikh, ikh napravlenie $\mathrm{i}$ formu otchyotnosti', pp.40-41.

203. Gaysa Hüseyinov, Rizaitdin bin Fehritdin (Ufa, 1997), pp.204-5.

204. 'Vozzvanie i obrashchenie k bratyam musul'manam musul'manskikh stran', Biulleten' Tsentral'noi Komissii Pomoshchi Golodaiushchim VTsIK, Nos.5-7 (Feb.-April 1922), pp.39-40.

205. Musa Carullah Bigi (edited by İsmail Türkoğlu), 'Tarihin Unutulmuş Sahifeleri', Türk Dünyası Araştırmalarl (Istanbul), No.110 (Oct. 1997), pp.113-14. Although these memoirs were published under Musa Carullah Bigi's name for an unknown reason, they actually belonged to Abdürreşid İbrahim.

206. 'Aç Kardeşlerimizin Murahhasları Şehrimizde', Anadolu'da Yeni Gün (Ankara), 28 July 1922.

207. 'Obrashchenie k musul'manam vsego mira', Rossiiskii Tsentr Khraneniya i Izucheniya Dokumentov Noveishei Istorii (Russian Center for the Preservation and Study of Documents of Most Recent History) (Moscow), f. 80, op.6, d. 15, 11. 1-2.

208. Hüseyinov, p.204.

209. 'Beyannâme. Yeryüzünde Mevcut Bütün Müslümanlara', BCA, Diyanet İşleri Reisliği Fonu, No.051/8.66.31 (31 Dec. 1923).

210. Ibid.

211. 'Rusya'daki Müslümanlar', İkdam (Istanbul), 28 Aug. 1922.

212. [Keşşafüddin Tercümânî] K. Tercümanov, 'Oproverzhenie lozhnykh soobshchenii, napechatannykh v Tatarskoi gazete 'Eșçi' /Rabochii/, izdaiushcheisya v g. Moskve v no.No.19, 21, 26 e/g.', GARF, f. R-393 (People's Commissariat of Internal Affairs [NKVD RSFSR]), op.43A, d. 8, 1. 15 .

213. 'Rusya Açları', Vakit (Istanbul), 27 June 1922.

214. 'Aç Kardeşlerimizin Murahhasları Şehrimizde', Anadolu'da Yeni Gün (Ankara), 28 July 1922.

215. Tercümanov, 'Oproverzhenie ...' (note 212).

216. 'Rusya'da Açlık ve Sefaletin Derecesi', Vakut (Istanbul), 29 June 1922. For a similar interview with Bûbî where he depicted the lamentable situation of the famished Muslims of the Volga-Ural region, see, 'Rusya'daki Aç Kardaşlarımız İçin', İkdam, 11 Aug. 1922.

217. 'Rusya'daki Aç Kardaşlarımız İçin', İkdam (Istanbul), 11 Aug. 1922; 'From the General Secretary of the Ottoman Red Crescent Society to the Red Crescent Delegation in Ankara, 11 July 1922', TKDMA, dosya no. 331-5/1922.

218. 'Aç Kardeşlerimizin Murahhasları Şehrimizde', Anadolu'da Yeni Gün, 28 July 1922.

219. 'From the General Secretary of the Ottoman Red Crescent Society to the Red Crescent Transmission Office in İnebolu, 11 July 1922' and 'From the General Secretary of the Ottoman Red Crescent Society to the Ankara Delegation of the Red Crescent Society, 11 July 1922', TKDMA, dosya no. 331-5/1922. As these documents and news items did not mention the name of Tahir İlyâsî, in all likelihood he did not come to Ankara.

220. 'Aç Kardeşlerimizin Murahhasları Şehrimizde', Anadolu'da Yeni Gün (Ankara), 28 July 1922.

221. 'Rusya Müslümanlarına Muavenet', Hakimiyet-i Milliyye (Ankara), 1 Aug. 1922.

222. 'Rusya'daki Türklerin Açlı̆̆ı', İkdam (Istanbul), 13 Aug. 1922.

223. 'Rusya'daki Müslümanlar', İkdam (Istanbul), 28 Aug. 1922.

224. Ibid.; 'Şimal Türkleri Murahhasları', Ikdam (Istanbul), 12 Aug. 1922. 
225. 'Rusya'daki Müslümanlar', İkdam (Istanbul), 28 Aug. 1922.

226. 'Rusça Tedris İçin Mektep', Anadolu'da Yeni Gün (Ankara), 23 May 1922.

227. 'Kırım Murahhası', Anadolu'da Yeni Gün (Ankara), 9 July 1922.

228. Ahmed Hidayet, 'Anadolu Mektupları-Kırım Murahhasında Bir Akşam', İkdam (Istanbul), 24 July 1922.

229. Ibid.

230. 'Protokol No.8. Ob'edinennogo zasedaniya Prezidiumov Kr. TsIK'a, Krymsovnarkoma i Krym TsKPG, 13-go Oktyabrya 1922 goda', GARF, f. R-393, op.35, d. 589, 1. 49.

231. 'Hilâl-i Ahmer ve Kırım Açları', İkdam (Istanbul), 20 July 1922.

232. 'Hilâl-i Ahmer Kırım İmdad ve Muavenet Heyeti', Vaktt (Istanbul), 1 Aug. 1922. According to the first plan, the relief material was to taken by Ali Mâcid Bey, a professor at Istanbul University.

233. 'Sevastopol Müslümanlarının Tezâhürâtı', Vaktt (Istanbul), 23 Sept. 1922.

234. 'Rusya'daki Müslüman Kardaşlar', Hakimiyet-i Milliyye, 29 Sept. 1922; 'Rusya ve Tebriz Müslümanları ve Zaferimiz', İkdam (Istanbul), 30 Sept. 1922.

235. 'Türkiye Hilâl-i Ahmeri'nin Kırım Müslüman Açlarına Yardımı', Yeni Dünya (Akmescit/Simferopol), 21 Sept. 1922. According to an account in the Istanbul daily Tevhîd-i Efkâr, Ubeydullah Bûbî and Tahir İlyâsî were also on the same steamer. 'Rusya'daki Müslümanlar', Tevhîd-i Efkâr (Istanbul), 21 Nov. 1922.

236. 'Kırım Açlarına Yardım', Türkiye Hilâl-i Ahmer Mecmuası (Istanbul), No.18 (15 Jan. 1923), p.121.

237. 'Rusya'daki Müslümanlar', Tevhîd-i Efkâr, 21 Nov. 1922. That the relief was a special Holiday of Sacrifice gift of the Anatolian Muslims to the Crimean Muslims was also emphasized by the Red Crescent. 'From the General Centre of the Red Crescent to the Crimean Central Pomgol, No.1783 [date missing]', TKDMA, dosya no.331-5/1922.

238. 'Rusya'daki Müslümanlar', Tevhîd-i Efkâr (Istanbul), 21 Nov. 1922; Türkiye Hilâl-i Ahmer Mecmuasl (Istanbul), No.18 (15 Jan. 1923), p.121.

239. 'The distribution list of the 2,000 sacks of flour and 696 cases of dried vegetables and canned food sent by the Ottoman Red Crescent Society to the starving Muslims (Spisok raspredeleniva mezhdu golodaiushchimi musul'manami 2000 meshkov muki i 696 yashchikov sushchennykh ovoshchei $i$ konservov, prislannykh Obshchestvom Ottomanskogo Krasnogo Polumesyatsa)', TKDMA, dosya no.331-5/1922. According to this list, the distribution of the sacks of flour and the canned food was to be as follows: raion of Sudak: 324 sacks; village of Üsküt: 53 sacks; raion of Canköy: 129 sacks; village of Bagatır and its surroundings: 304 sacks; Yalta, Alupka, and their surroundings: 215 sacks; raion of Bakkal in Kezlev/Yevpatoriya: 215 sacks; Akmescit/Simferopol and its surroundings: 161 sacks; Karasubazar and its surroundings: 80 sacks; Kefe/Feodosiya and its surroundings: 161 sacks; village of Baydar and its surroundings: 80 sacks; Bahçesaray and its surroundings: 80 sacks; Büyük Onlar and its surroundings: 61 sacks; city of Sevastopol (Akyar) five sacks; Muslim teachers in the above places: 32 sacks; the Crimean Tatar Girls' Teachers' School: 60 sacks; and the Crimean Tatar Technical Secondary School in Totayköy: 40 sacks. 656 cases of dried fruit and 40 cases of canned consommé were to be distributed to Muslim children's shelters in the above places.

240. 'Rusya'daki Müslümanlar', Tevhîd-i Efkâr (Istanbul), 21 Nov. 1922; 'Kırım Açlarına Yardım', Türkiye Hilal-i Ahmer Mecmuasi (Istanbul), No.18 (15 Jan. 1923), pp.121-2. Abdürreşid İbrahim recounted that some 15-20 carloads of relief material came to the Volga-Ural region from Turkey accompanied by Turkish soldiers, and theır commanding officer who had no winter overcoat fell very ill and died there. He even mentioned that during the forthcoming All-Russian Muslim Clergymen Congress in 1923 the participants of the congress prayed for the soul of that officer. 'Tarihin Unutulmuş Sahifeleri', p.114. Although it is known that İbrahim Hakkı Bey fell ill and spent a week in bed in Kazan, no cases of death are recorded during his visit. One can speculate that either Abdürreşid İbrahim was confused or misinformed about İbrahim Hakk1's illness or there was actually another party of Turkish relief to the Volga-Ural region about which no records are known so far. 
241. One intellectual who received individual parcels was Gabdulla İbrahimov 'Şinâsî' from Ufa. This prominent Volga Tatar pedagogue and writer sent a letter to the Red Crescent on 13 Dec. 1922. He thanked them for the parcel he received through the ARA two months ago and in the face of the continuing troubles especially for the intellectuals requested another parcel with food and clothing. The Red Crescent was unable to meet this request due to the 'unfavourable circumstances and the distance' as decided by the Red Crescent's Ankara Delegation on 17 January 1922. This probably also concluded the Red Crescent's relief to the Volga-Ural region. 'From Abdullah [Gabdulla] Şinasî İbrahimov to the Ottoman Red Crescent, Ufa, 13 Dec. 1922', TKDMA, dosya No.331-5/1922.

242. A document from the Karasubazar Raion Executive Committee testified that 80 sacks of white flour, 30 cases of canned food, and two of fish had been received and already been distributed to the starving Crimean Tatars in Karasubazar. 'The 'Official Note' (Sluzhebnaya zapiska) of the Karasubazar Raion Executive Committee, 16 Nov. 1922', TKDMA, dosya no.331-5/1922. There must have been similar documents in the archives which may surface with further research.

243. 'Kırım Açlarına Yardım', Türkiye Hilâl-i Ahmer Mecmuası, No.18 (15 Jan. 1923), pp.122, 124. Such a problem emerged when 217 sacks of flour which had been earmarked for Yalta and Alupka were directed to the children's shelters elsewhere. The incident was closed with the apologies on the part of the government and its pledge to replace them. The Red Crescent officials followed up the incident to see whether the pledge was to be fulfilled through a local proxy. 'From İbrahim Naci to İbrahim Hakk1 Bey, Representative of the Ottoman Red Crescent in the Crimea, 21 November 1922', TKDMA, dosya no.331$5 / 1922$.

244. 'From the Central Commission of Pomgol of the Crimean ASSR to the General Centre of the Red Crescent, Akmescit/Simferopol, 21 Sept. 1922', TKDMA, dosya no.331-5/1922. The letter was signed by Bekir Çobanzâde (Member of the Presidium of the Crimean Central Executive Committee), Shvedov (Deputy President of the Crimean Central Pomgol), Ayşe İshakova (Member of the Presidium of the Crimean Central Pomgol), Semyon Mikhailovich Poplavskii (Member of the Presidium of the Crimean Central Pomgol), and F. Katsman (Deputy Representative of Pomgol for the okrug of Sevastopol). The letter was written in two versions, Turkish and Russian. The Turkish version was published in the official journal of the Red Crescent with some printing errors, notably the date was given as 21 Oct., whilst in both the Turkish and Russian versions which are preserved in the Archives of the Red Crescent, the original date is clearly 21 September. See, 'Kırım Açlarına Yardım', Hilâl-ı Ahmer Mecmuası (Istanbul), No.18 (15 Jan. 1923), pp.124-5.

245. 'The Address of the Crimean ASSR Central Executive Committee to the Relief Committee for the Starving in the Crimea (KAYH) in Ankara, 7 October 1922', TKDMA, dosya no.331-5/1922.

246. 'From Habibullah Odabas and Osman Akçokraklı to Faik Bey and Hakkı Bey, Akmescit/Simferopol, 1 Oct. 1922', TKDMA, dosya no.331-5/1922. A letter thanking wholeheartedly for the relief also came from the students' representatives of both the Girls' Teachers' School (H. Kadızâde and Hasibe Abdülkuddus) and the Obstetrical School (A. Refatova and an unintelligible name). 'From the Students' Representatives of the Crimean Tatar Girls' Teachers' School and the Crimean Tatar Obstetrical School to Hakk1 Bey, Akmescit/Simferopol, 18 November 1922', TKDMA, dosya no.331-5/1922.

247. 'From Keşşâüddin Tercümânî, Chairman of the Relief Committee for the Starving of the Central Spiritual Board of the Muslims of Inner Russia and Siberia, to the Ottoman Red Crescent, Moscow, 8 Dec. 1922', TKDMA, dosya no.331-5/1922. For a published version of this letter, see, 'Kırım Açlarına Yardım', Türkiye Hilal-ı Ahmer Mecmuası (Istanbul), No.18 (15 Jan. 1923), p.125.

248. The declaration was signed by Rizaeddin Fahreddin (Honorary Chairman of the Congress), Ziyaeddin bin Kemâli (Chairman of the Congress), and Șehir Șeref (Chief Secretary of the Congress). 'Rusya Müslümanlarının Hilâl-i Ahmer'e Teşekkürü', Türkiye Hilâl-ı Ahmer Mecmuast (Istanbul), No.27 (15 Nov. 1923), pp.64-5. 
249. Fisher, p.374.

250. Baranchenko, pp.128-9.

251. Zarubin and Zarubin, p.38

252. 'Kırım Açlarına Yardım', Türkiye Hilâl-i Ahmer Mecmuası (Istanbul), No.49 (15 Sept. 1925), p. 173.

253. Çapa, p. 156

254. For this help, in the name of the members of the former Azerbaijani parliament, Dr Musa Refî sent a letter of gratitude to the Red Crescent on 29 Oct. 1922. 'İki Kardaş Millet Arasında', Osmanlı Hilâl-i Ahmer Mecmuast (Istanbul), No.15 (15 Nov. 1922), p.71. The Red Crescent offered 3,000 Ottoman liras of aid in cash to the Azerbaijani refugees. Türkiye Hilâl-i Ahmer Cemiyeti Merkez-i Umumîsi Tarafindan 1339 Senesi Hilâl-i Ahmer Meclis-i Umumîsi'ne Takdim Edilen (1335-1338) Dört Senelik Devreye Ait Rapor, p.141.

255. Çapa, p.157.

256. 'Hristiyan Gürcü Muhacirlerine Muavenet', Türkiye Hilâl-ı Ahmer Mecmuası', No.24 (15 Aug. 1923), pp.331-2.

257. The Red Crescent offered equipment for the feeding centres set up by the ARA and the embassies of the Entente Powers in Istanbul, as well as appliances and furniture for a 25bed hospital and a modest financial contribution (500 Ottoman liras) for this institution. Türkiye Hilâl-i Ahmer Cemiyeti Merkez-i Umumîsi Tarafindan 1339 Senesi Hilâl-i Ahmer Meclis-i Umumîsi'ne Takdim Edilen (1335-1338) Dört Senelik Devreye Ait Rapor, pp.140-41. 